Fournal of Medical Genetics (1970). 7, 315.

\title{
A Family Study of Neonatal and Late-diagnosis Congenital Dislocation of the Hip
}

\section{RUTH WYNNE-DAVIES}

\author{
From the Department of Orthopaedic Surgery, University of Edinburgh .
}

Only during the past 10 years has it been generally appreciated that congenital dislocation of the hip (CDH) can be found in the newborn child if looked for specifically within the first few days of life. Befor this, diagnosis was usually made only after the child started to walk. During the past decade there has been at least a fourfold increase in the number of infants attending for treatment. Previous epidemiological and genetic studies have mostly not included the group with neonatal diagnosis. There is, in fact, no certainty that they are both of the same aetiology, and the present survey was undertaken with the object of studying neonatal $\mathrm{CDH}$ (diagnosed during the first 4 weeks of life, usually in the first week) and late-diagnosis $\mathrm{CDH}$ (diagnosed after the first 4 weeks, usually many months or years later). Only primary congenital dislocation is considered here, not cases associated with arthrogryposis or paralytic dislocation secondary to spina bifida and cerebral palsy.

An attempt has been made to establish the incidence, and to determine the family aggregation of cases, parental age, birth order, pregnancy history, season of birth, and social class. In addition, an investigation relating to familial joint laxity and to acetabular dysplasia in $\mathrm{CDH}$ has been carried out, but these clinical findings will only be summarized here and details reported in another paper.

\section{Incidence of Neonatal CDH}

It is known that the number of neonatal $\mathrm{CDH}$ cases diagnosed depends not only whether the deformity is looked for specifically by a competent examiner, but also on when, during the first week of life, the examination is made. The hip can easily be 'clicked' in and out of joint in the first two or three days of life, and more cases will be found then then in the second three days, when the child's muscles have tightened and the sign can no longer be elicited (Barlow, 1962; Nelson, 1966; Thieme et al., 1968).

Received 20 March 1970.
Thus, the population incidence of neonatal $\mathrm{CDH}$ appears to fluctuate more widely than is the case with more easily observed deformities, though it is probable also that there are wide racial and geographical differences. During the period that specific examination of the neonate has been carried out, figures from England include the following: Barlow (1962) 139 of 9289-15.0/1000 live births (about half these hips were classed as 'unstable', not dislocated); Wilson (1964) 35 of $5700-6 \cdot 1 / 1000$ live births; Finlay, Maudsley, and Busfield (1967) 60 of 14,594-4.1/1000 live births. In Edinburgh a Congenital Malformations Register was established in 1964, and figures from it for neonatal $\mathrm{CDH}$ during the period of this survey are as follows- 1965: 69 of $11,080-6 \cdot 2 / 1000$ live births; $1966: 42$ of 10,698 $3 \cdot 9 / 1000$ live births.

These figures must include some patients (though it is impossible to know which ones) who, 10 years ago, would have presented as late-diagnosis $\mathrm{CDH}$ as this is a diagnosis now rarely made in the city of Edinburgh, where some $90 \%$ of births are institutional and neonatal screening is good.

\section{Incidence of Late-diagnosis CDH}

It is unfortunately impossible in retrospect accurately to ascertain this figure, as hospital diseaseindexing systems are very incomplete. However, unlike neonatal $\mathrm{CDH}$, this is a well-defined group in which there is invariably deformity and no doubt as to diagnosis. In the decade before 1960 (i.e. before the diagnosis of $\mathrm{CDH}$ in the neonatal period became commonplace) it was found that the numbers attending hospital for treatment were approximately one-quarter of the present numbers. Thus, a figure of about 1 per 1000 live births for latediagnosis $\mathrm{CDH}$ is thought to be reasonable. This figure is comparable with those of other surveys which were carried out before neonatal $\mathrm{CDH}$ was well established (Record and Edwards (1958) 0.65/ 1000; McIntosh et al. (1954) 1·6/1000). 
The current figure for late-diagnosis $\mathrm{CDH}$ in the city of Edinburgh has now dropped to $0 \cdot 13 / 1000$ (G. P. Mitchell, 1970, personal communication). This is accounted for by the occasional child with a 'tight' dislocation who was examined at birth and in whom it was not possible to 'click' the hip in and out of joint. Thus, the dislocation was missed until some months later. It should be noted that latediagnosis $\mathrm{CDH}$ cases continue to come in from the outlying areas which have less adequate facilities for neonatal screening.

\section{Material and Method for Family Study}

This survey has been undertaken on the patients from two large orthopaedic clinics, one from the Princess Margaret Rose Orthopaedic Hospital, Edinburgh, and the other from the Royal Hospital for Sick Children, Glasgow. There were 589 index patients (Table I).

TABLE I

\begin{tabular}{l|l|c|c|c}
\hline & & Edinburgh & Glasgow & Total \\
\hline Neonatal CDH & Male & 42 & 3 & 45 \\
& Female & 140 & 7 & 147 \\
\cline { 2 - 5 } Late-diagnosis CDH & Total & 182 & 10 & 192 \\
\cline { 2 - 5 } & Male & 18 & 34 & 52 \\
& Female & 186 & 159 & 345 \\
\cline { 2 - 5 } & Total & 204 & 193 & 397 \\
\cline { 2 - 5 } & Total & 386 & 203 & 589 \\
\hline
\end{tabular}

In view of the uncertainty of diagnosis in neonatal $\mathrm{CDH}$, it was considered preferable to include patients only from these orthopaedic clinics with their standardized methods of diagnosis and treatment, rather than attempt a complete survey of the area. It was, however, ascertained from the Congenital Malformations Register for Edinburgh that $75 \%$ of the 111 neonatal CDH cases recorded in 1965 and 1966 were included in this survey. The records of the remaining $25 \%$ on the Register were checked to ensure they differed in no way from the $75 \%$ sample included here. The points noted were the sex ratio, side of deformity, pregnancy, and perinatal history, social class, season of birth, and family history of $\mathrm{CDH}$. The other neonatal cases in the survey were attending the orthopaedic clinics during 1965 and 1966, but were resident outside Edinburgh.

The late-diagnosis $\mathrm{CDH}$ patients were all who could be traced from current and old hospital notes dating back to 1932. This cannot be a complete survey of the area, but it is extremely unlikely it is anything but a large random sample.

All 589 index patients were examined either by myself or one of two medically qualified assistants of the former Medical Research Council Research Group on Genetic Problems in Orthopaedic Disease, and an attempt was made to see all first degree relatives either as they attended for a routine clinic visit or by appointment in their own
TABLE II

CDH SURVEY-TRACING OF FIRST DEGREE RELATIVES

(589 index patients)

\begin{tabular}{l|c|c|c|c|c|c}
\hline & $\begin{array}{c}\text { Total } \\
\text { No. }\end{array}$ & Dead & $\begin{array}{c}\text { Not } \\
\text { Traced } \\
\text { or } \\
\text { Overseas }\end{array}$ & $\begin{array}{c}\text { Avail- } \\
\text { able } \\
\text { for } \\
\text { Visiting }\end{array}$ & $\begin{array}{c}\text { Refused } \\
\text { to } \\
\text { Co- } \\
\text { operate }\end{array}$ & Examined \\
\hline Fathers & 589 & 45 & 79 & 465 & 13 & 452 \\
Mothers & 589 & 24 & 25 & 540 & 5 & 535 \\
Brothers & 565 & 65 & 108 & 392 & 9 & 383 \\
Sisters & 549 & 52 & 73 & 424 & 4 & 420 \\
Sons & 53 & -2 & 7 & 46 & - & 46 \\
Daughters & 67 & 2 & 4 & 61 & - & 61 \\
\hline \multicolumn{1}{c|}{ Total } & 2412 & 188 & 296 & 1928 & 31 & 1897 \\
\hline
\end{tabular}

homes, whether in Scotland, England, or Wales. Of those available for visiting $\mathbf{9 8 . 4} \%$ were seen and only $1.6 \%$ refused (Table II).

A history was taken relating to $\mathrm{CDH}$ and other congenital or developmental anomalies among second and third degree relatives (first cousins only), and, if positive, these individuals were either visited or confirmation of the diagnosis obtained from local medical records. Hearsay evidence only was not accepted.

Examination for excessive joint laxity was carried out in all index patients and all first degree relatives who could be traced. In the acetabular dysplasia investigation, radiographic examination of the hips was carried out in the apparently normal parents of 162 index patients (95 neonatal and 67 late-diagnosis $\mathrm{CDH}$ ). This part of the survey was continued only until there were adequate numbers for analysis. Control groups from the normal population were also obtained for joint laxity and acetabular dysplasia.

\section{Results}

Sex ratio. There was the usual marked preponderance of females in both neonatal and latediagnosis $\mathrm{CDH}$, the sex ratio being 0.31 in the neonates, and 0.15 in the late-diagnosis group.

Parental consanguinity. There was only one instance of parental consanguinity, the parents being first cousins and having one male neonatal $\mathrm{CDH}$ child. The parents and three sibs (two brothers and one sister) were normal.

Familial incidence. The 589 index patients were drawn from 559 families, there being a number of instances of more than one index case in the same family. In 26 cases a double count was used, and in 2 cases a treble count. (Details of kindreds (first degree relatives) are shown in the Appendix.)

Twins. There were five twin pairs in the survey, as follows:

$\begin{array}{ll}M Z \text { females (neonatal CDH) } & \text {-concordant } \\ M Z \text { males (late-diagnosis CDH) } & \text {-discordant } \\ \mathrm{DZ} \text { females (two pairs, late-diagnosis CDH)-discordant } \\ \mathrm{DZ}\left\{\begin{array}{l}\text { male (neonatal CDH) } \\ \text { female (late-diagnosis } \mathrm{CDH})\end{array}\right\} & \text {-concordant }\end{array}$


TABLE III

PROPORTION OF FIRST DEGREE RELATIVES WITH NEONATAL AND LATE-DIAGNOSIS CDH

\begin{tabular}{|c|c|c|c|c|c|c|}
\hline Index Patients & Fathers & Mothers & Brothers & Sisters & Sons & Daughters \\
\hline $\begin{array}{l}\text { Neonatal } C D H \\
\text { Male index (45) }\end{array}$ & $0 / 45$ & $1 / 45$ & $1 * / 18$ & $1 *+4 / 25$ & 一 & - \\
\hline Female index (147) & $0 / 147$ & $\begin{array}{l}(2.2 \%) \\
2 / 147 \\
(1 \cdot 4 \%)\end{array}$ & $\begin{array}{c}(5 \cdot 6 \%) \\
1 * 1 / 86 \\
(2 \cdot 3 \%)\end{array}$ & $\begin{array}{c}(20 \%) \\
13^{*}+7 / 78 \\
(25 \cdot 6 \%)\end{array}$ & - & - \\
\hline Total (192) & $0 / 192$ & $\begin{array}{c}3 / 192 \\
(1.6 \%)\end{array}$ & $\begin{array}{c}2 *+1 / 104 \\
(2.9 \%)\end{array}$ & $\begin{array}{c}14^{*}+11 / 103 \\
(24 \cdot 3 \%)\end{array}$ & - & - \\
\hline $\begin{array}{l}\text { Late-diagnosis CDH } \\
\text { Male index (52) }\end{array}$ & $0 / 52$ & $1 / 52$ & $0 / 61$ & $1 *+4 / 53$ & $0 / 3$ & $0 / 4$ \\
\hline Female index (345) & $\begin{array}{l}1 / 345 \\
(0.3 \%)\end{array}$ & $\begin{array}{c}(1.9 \%) \\
4 / 345 \\
(1 \cdot 2 \%)\end{array}$ & $\begin{array}{c}3 *+4 / 369 \\
(1 \cdot 9 \%)\end{array}$ & $\begin{array}{c}13^{*}+18 \% / 376 \\
(8 \cdot 2 \%)\end{array}$ & $\begin{array}{l}3 * / 51 \\
(5 \cdot 9 \%)\end{array}$ & $\begin{array}{l}9 *+3 / 66 \\
(18 \cdot 2 \%)\end{array}$ \\
\hline Total (397) & $\begin{array}{c}1 / 397 \\
(0.3 \%)\end{array}$ & $\begin{array}{c}5 / 397 \\
(1 \cdot 3 \%)\end{array}$ & $\begin{array}{c}3 *+4 / 430 \\
(1.6 \%)\end{array}$ & $\begin{array}{c}14^{*}+22 / 429 \\
(8 \cdot 4 \%)\end{array}$ & $\begin{array}{l}3 * / 54 \\
(5 \cdot 6 \%)\end{array}$ & $\begin{array}{l}9 *+3 / 70 \\
(17 \cdot 1 \%)\end{array}$ \\
\hline Grand total (589) & $\begin{array}{c}1 / 589 \\
(0.2 \%)\end{array}$ & $\begin{array}{c}8 / 589 \\
(1 \cdot 4 \%)\end{array}$ & $\begin{array}{c}5 *+5 / 534 \\
(1.9 \%)\end{array}$ & $\begin{array}{c}28 *+33 / 532 \\
(11 \cdot 5 \%)\end{array}$ & $\begin{array}{c}3 * / 54 \\
(5 \cdot 6 \%)\end{array}$ & $\begin{array}{l}9 *+3 / 70 \\
(17 \cdot 1 \%)\end{array}$ \\
\hline
\end{tabular}

* Neonatal CDH. All other affected relatives were late-diagnosis CDH.

The diagnosis of mono- or dizygotic twins was made on clinical examination only.

First degree relatives. The proportion of affected first degree relatives is shown in Table III.

It is necessary to distinguish between the affected relatives diagnosed in recent years when many neonatal cases will be included, and those before 1960, which consist of late-diagnosis $\mathrm{CDH}$ only. It is noted that the proportion of affected sibs in neonatal $\mathrm{CDH}(13.5 \%)$ is similar to that of affected children in late-diagnosis $\mathrm{CDH}(12 \cdot 1 \%)$, both these groups being largely post-1960 diagnoses. The figures for parents will relate to late-diagnosis $\mathrm{CDH}$ only.

In comparing the familial with the population incidence, the 'expected' figures shown are based on incidence values of $1 / 1000$ and 4/1000 (Table IV). The increase of observed over expected figures is highly significant in each case. There was no significant difference in the proportions of affected relatives of the male and female index patients. There were many more affected female than male relatives: 14 of $1177(1.2 \%)$ males, compared with 81 of $1191(6.8 \%)$ females. This is to be expected from the known sex ratio of the disorder. These findings are comparable with those in studies from Birmingham (Record and Edwards, 1958) and London (Carter, 1970).

Second and third degree relatives. The proportions of affected second and third degree relatives are given in Tables V and VI. As the information was gained only by history taking (and confirmation from medical records), it is likely that it is less complete for the second degree relatives, many of whom were elderly or dead, than for the third, as these were all first cousins and mostly contemporary with the index patients.

The over-all incidence amongst second degree relatives is 22 of $6664(0.33 \%)$. The same

TABLE IV

CONGENITAL DISLOCATION OF HIP IN FIRST DEGREE RELATIVES

\begin{tabular}{|c|c|c|c|c|c|c|}
\hline & \multirow{2}{*}{ No. } & \multicolumn{3}{|c|}{ Affected (Observed) } & \multicolumn{2}{|c|}{$\begin{array}{l}\text { General Population } \\
\text { Incidence Expected } \\
\text { Figure Based On: }\end{array}$} \\
\hline & & $\begin{array}{l}\text { Neonatal } \\
\text { CDH in } \\
\text { Relatives }\end{array}$ & $\begin{array}{c}\text { Late- } \\
\text { diagnosis } \\
\text { CDH in } \\
\text { Relatives }\end{array}$ & Total & $1 / 1,000$ & $4 / 1,000$ \\
\hline $\begin{array}{l}192 \text { Neonatal } C D H \\
\text { Parents } \\
\text { Sibs } \\
\text { 397 Late-diagnosis } C D H \\
\text { Parents } \\
\text { Sibs } \\
\text { Children }\end{array}$ & $\begin{array}{l}384 \\
207 \\
794 \\
859 \\
124\end{array}$ & $\begin{array}{l}\overline{16} \\
\overline{17} \\
12\end{array}$ & $\begin{array}{r}3 \\
12 \\
6 \\
26 \\
3\end{array}$ & $\begin{array}{c}3(0.8 \%) \\
28(13.5 \%) \\
6(0.8 \%) \\
43(5.0 \%) \\
15(12 \cdot 1 \%)\end{array}$ & $\begin{array}{l}0.38 \\
0.21 \\
0.79 \\
0.86 \\
0.12\end{array}$ & $\begin{array}{l}0 \cdot \overline{84} \\
\overline{3 \cdot 44} \\
0 \cdot 48\end{array}$ \\
\hline
\end{tabular}


TABLE V

PROPORTIONS OF AFFECTED 2nd DEGREE RELATIVES WITH NEONATAL AND LATE-DIAGNOSIS CDH

\begin{tabular}{|c|c|c|c|c|c|c|c|c|c|c|c|}
\hline Index Patients & $\begin{array}{l}\text { Grand- } \\
\text { fathers }\end{array}$ & $\begin{array}{l}\text { Grand- } \\
\text { mothers }\end{array}$ & Uncles & Aunts & $\mid \begin{array}{c}\text { Half- } \\
\text { brothers }\end{array}$ & $\begin{array}{l}\text { Half- } \\
\text { sisters }\end{array}$ & $\begin{array}{c}\text { Grand- } \\
\text { sons }\end{array}$ & $\begin{array}{l}\text { Grand- } \\
\text { daughters }\end{array}$ & & Nephews & Nieces \\
\hline \multicolumn{12}{|l|}{ Neonatal $C D H$} \\
\hline $\begin{array}{l}\text { Paternal side } \\
\text { Maternal side }\end{array}$ & $\begin{array}{l}0 / 45 \\
0 / 45\end{array}$ & $\begin{array}{l}0 / 45 \\
0 / 45\end{array}$ & $\begin{array}{l}0 / 65 \\
0 / 65\end{array}$ & $\begin{array}{l}0 / 62 \\
0 / 52\end{array}$ & $\overline{0 / 2}$ & $0 / 2$ & 二 & 二 & $\begin{array}{l}\text { Brothers' children } \\
\text { Sisters' children }\end{array}$ & 三 & 二 \\
\hline $\begin{array}{c}\text { Female index } \\
\text { (147) }\end{array}$ & & & & & & & & & & & \\
\hline $\begin{array}{l}\text { Paternal side } \\
\text { Maternal side }\end{array}$ & $\begin{array}{l}0 / 147 \\
0 / 147\end{array}$ & $\begin{array}{l}0 / 147 \\
0 / 147\end{array}$ & $\begin{array}{l}0 / 232 \\
1 / 251\end{array}$ & $\begin{array}{l}0 / 208 \\
2 / 205\end{array}$ & $0 / 2$ & $\begin{array}{r}* 1 / 2 \\
0 / 1\end{array}$ & 二 & 二 & $\begin{array}{l}\text { Brothers' children } \\
\text { Sisters' children }\end{array}$ & 二 & $\overline{0 / 1}$ \\
\hline \multicolumn{12}{|l|}{$\begin{array}{c}\text { Late-diagnosis } C D H \\
\text { Male index (52) }\end{array}$} \\
\hline Paternal side & $0 / 52$ & $0 / 52$ & $08 / 8$ & $0 / 89$ & $0 / 4$ & $\overline{0}$ & $\overline{0 / 2}$ & $\overline{010}$ & Brothers' children & $0 / 15$ & $* 1 / 14$ \\
\hline $\begin{array}{l}\text { Maternal side } \\
\text { Female index }\end{array}$ & $0 / 52$ & $0 / 52$ & $0 / 101$ & $1 / 120$ & $0 / 4$ & $0 / 2$ & $0 / 2$ & $0 / 2$ & Sis & $0 / 9$ & $0 / 10$ \\
\hline $\begin{array}{l}\text { Paternal side } \\
\text { Maternal side }\end{array}$ & $\begin{array}{l}0 / 345 \\
0 / 345\end{array}$ & $\begin{array}{l}1 / 345 \\
0 / 345\end{array}$ & $\begin{array}{l}0 / 59 \\
1 / 54\end{array}$ & $\begin{array}{l}2 / 575 \\
6 / 543\end{array}$ & $\begin{array}{l}0 / 13 \\
0 / 12\end{array}$ & $\begin{array}{l}0 / 12 \\
1 / 12\end{array}$ & $\overline{0 / 8}$ & $\overline{0 / 9}$ & $\begin{array}{l}\text { Brothers' children } \\
\text { Sisters' children }\end{array}$ & $\begin{array}{l}0 / 88 \\
* 1 / 107\end{array}$ & $\begin{array}{l}1 / 81 \\
3 / 98\end{array}$ \\
\hline
\end{tabular}

* Neonatal CDH, all other affected relatives were late-diagnosis CDH.

TABLE VI

PROPORTIONS OF AFFECTED 3rd DEGREE RELATIVES (1st COUSINS ONLY) WITH NEONATAL AND LATE-DIAGNOSIS CDH

\begin{tabular}{|c|c|c|c|c|c|c|c|c|}
\hline \multirow{3}{*}{ Index Patients } & \multicolumn{4}{|c|}{ Paternal Side } & \multicolumn{4}{|c|}{ Maternal Side } \\
\hline & \multicolumn{2}{|c|}{ Uncles' Children } & \multicolumn{2}{|c|}{ Aunts' Children } & \multicolumn{2}{|c|}{ Uncles' Children } & \multicolumn{2}{|c|}{ Aunts' Children } \\
\hline & Male & Female & Male & Female & Male & Female & Male & Female \\
\hline $\begin{array}{l}\text { Neonatal CDH } \\
\text { Male index (45) } \\
\text { Female index (147) } \\
\text { Late-diagnosis } C D H\end{array}$ & $\begin{array}{l}0 / 44 \\
0 / 107\end{array}$ & $\begin{array}{l}0 / 42 \\
0 / 126\end{array}$ & $\begin{array}{c}0 / 48 \\
1 * / 131\end{array}$ & $\begin{array}{c}0 / 43 \\
1 * / 135\end{array}$ & $\begin{array}{l}1 * / 28 \\
0 / 108\end{array}$ & $\begin{array}{c}0 / 14 \\
1 * / 105\end{array}$ & $\begin{array}{l}0 / 20 \\
0 / 123\end{array}$ & $\begin{array}{r}0 / 31 \\
1 *+1 / 127\end{array}$ \\
\hline $\begin{array}{l}\text { Male index (52) } \\
\text { Female index (345) }\end{array}$ & $\begin{array}{l}0 / 58 \\
0 / 476\end{array}$ & $\begin{array}{c}1 / 47 \\
1 *+1 / 432\end{array}$ & $\begin{array}{l}0 / 78 \\
2 / 483\end{array}$ & $\begin{array}{c}0 / 76 \\
1 * 1 / 481\end{array}$ & $\begin{array}{l}0 / 97 \\
0 / 364\end{array}$ & $\begin{array}{c}1 / 71 \\
1 *+1 / 360\end{array}$ & $\begin{array}{l}0 / 149 \\
0 / 477\end{array}$ & $\begin{array}{r}0 / 104 \\
1^{*}+1 / 467\end{array}$ \\
\hline
\end{tabular}

* Neonatal CDH. All other affected relatives had late-diagnosis CDH.

preponderance of affected females, 19 of 3278 $(0.58 \%)$, is apparent when compared with affected males, 3 of $3386(0.09 \%)$. Among second degree relatives there was an increase $(\times 3)$ of the number of affected relatives on the maternal side of the family when compared with the paternal side, but little difference between the numbers of affected brothers' children $(1.0 \%)$ and sisters' children (1.8\%). Among third degree relatives the proportions of affected maternal and paternal were identical (0.3\%).

Parental age and birth order. The paternal age in relation to the maternal was noted. The fathers averaged 2.8 years older (mean for whole survey, for male and female index patients separately, and for neonatal and late-diagnosis groups separately). This does not differ significantly from the expected figure for the normal population.

The maternal age and birth order of the neonatal and late-diagnosis groups were compared with the Registrar General's figures for Scotland. A preponderance of first-born children was noted and this was found to be independent of a maternal age effect. The excess of first-born was highly significant for both neonatal and late-diagnosis groups (Table VII).

Pre- and perinatal factors. These were determined by questioning the mother, where possible, but as in all retrospective history taking the information may not be entirely accurate.

There was no evidence of undue maternal infection during pregnancy. Toxaemia of pregnancy

TABLE VII

BIRTH ORDER OF PATIENTS WITH CDH (EXPRESSED AS NUMBER OF PREVIOUS FREGNANCIES)

\begin{tabular}{|c|c|c|c|c|}
\hline Neonatal $C D H^{*}$ & 0 & 1 & $2+$ & Total \\
\hline $\begin{array}{l}\text { Observed } \\
\text { Expected }\end{array}$ & $\begin{array}{l}94 \\
68 \cdot 1\end{array}$ & $\begin{array}{l}54 \\
60 \cdot 3\end{array}$ & $\begin{array}{l}44 \\
63.6\end{array}$ & $\begin{array}{l}192 \\
192.0\end{array}$ \\
\hline $\begin{array}{l}\text { Late-diagnosis } C D H \dagger \\
\text { Observed } \\
\text { Expected }\end{array}$ & $\begin{array}{l}167 \\
121 \cdot 1\end{array}$ & $\begin{array}{l}102 \\
120 \cdot 4\end{array}$ & $\begin{array}{l}115 \\
142.6\end{array}$ & $\begin{array}{l}384 \\
384 \cdot 1\end{array}$ \\
\hline
\end{tabular}

$* \chi_{(2)}^{2}=16.55$ Highly significant.

$\dagger x(2)=25.55$ Highly significant. 
occurred in $7 \%$ of the mothers of late-diagnosis $\mathrm{CDH}$ patients, and in $10 \%$ of the mothers of neonatal $\mathrm{CDH}$ patients. This latter figure is a little higher than the usually quoted 'expected' figure of $7 \%$. A history of breech presentation or version late in pregnancy was obtained in $17.7 \%$ of the neonatal CDH patients (females $15.6 \%, 18$ breeches and 5 versions in 147 births; males $24.4 \%, 8$ breeches and 3 versions in 45 births); and in 17.9\% of late-diagnosis $\mathrm{CDH}$ patients (females $17.9 \%, 49$ breeches and 9 versions in 324 births; males $20.4 \%, 10$ breeches, no versions in 49 births; no history was available in 18 cases). It was not possible to determine how many were breech with extended legs, which is the presentation thought to be particularly associated with $\mathrm{CDH}$.

The mean birthweight of the neonatal $\mathrm{CDH}$ patients was $3448 \mathrm{~g}$. (females 3401 g., males 3492 g.), and of the late-diagnosis $\mathrm{CDH}$ patients $3088 \mathrm{~g}$. (females 3129 g., males 3039 g.). The mean for late-diagnosis $\mathrm{CDH}$ is exactly the same (3088 g.) as reported by Record and Edwards (1958), and is probably below the expected mean for this area. Unfortunately control figures are not available, and further investigation of both neonatal and latediagnosis birthweights is needed.

Season of birth. There was a preponderance of $\mathrm{CDH}$ births in the two winter quarters of the year (October to March), with a winter: summer ratio of 1.5 for neonatal $\mathrm{CDH}$ and 1.3 for late-diagnosis $\mathrm{CDH}$.

Social class. The socio-economic status of the patient's family was classified using the Registrar General's grading based on the father's occupation. No previous survey of late-diagnosis $\mathrm{CDH}$ has noted any social class effect, and none was observed in this study. However, the neonatal CDH group showed a significant increase in the proportions of social classes 1 and 2 (i.e. professional and managerial), whereas classes 3,4 , and 5 did not differ from the expected figures. This was apparent in the over-all figures for the whole group of 192 neonatal $\mathrm{CDH}$ when $25 \%$ were found to be of social class 1 and 2 instead of an expected figure of approximately $15 \%$. This was an unexpected finding and in order to establish it as accurately as possible the social class grading was repeated by a research worker from the Department of Social Medicine, University of Edinburgh, without being aware of the grades previously given. Only minor differences were noted. The social class of those neonates in this survey born only within the city of Edinburgh was then compared with the Registrar General's figures for the city, with approximately the same result (28\% in social classes 1 and 2). Finally, all cases of neonatal $\mathrm{CDH}$ recorded in the Edinburgh Congenital Malformations Register for three complete years (1965-1967) were compared with the Registrar General's figures for Edinburgh city (Table VIII), when $29.2 \%$ were found to be in social classes 1 and 2 compared with an expected figure of $18.8 \%$.

TABLE VIII

SOCIAL CLASS IN NEONATAL CONGENITAL DISLOCATION OF HIP

\begin{tabular}{l|c|c|c|c}
\hline & \multicolumn{4}{|c}{ Social Class } \\
\cline { 2 - 5 } & 1 and 2 & 3 & 4 and 5 & Total \\
\hline $\begin{array}{c}\text { Edinburgh city Neonatal } \\
\text { CDH (from Congenital } \\
\begin{array}{c}\text { Malformations Register) } \\
\text { Normal population } \\
\text { (Edinburgh, 1961) }\end{array}\end{array}$ & 45 & 66 & 40 & 151 \\
\hline
\end{tabular}

$x_{(2)}^{2}=11.05 ; 0.01>p>0.001$

In view of this finding, the whole survey (589 patients) was divided by social class and the incidence of $\mathrm{CDH}$ in sibs then recorded (Fig. 1). It is clear that there is a social class effect throughout, most obvious when neonatal $\mathrm{CDH}$ is included, but apparent to a lesser degree with late-diagnosis CDH also.

Genetic counselling. The risks of $\mathrm{CDH}$ to subsequent children in the family calculated on the whole survey (and including both neonatal and latediagnosis $\mathrm{CDH}$ ) are as follows: With normal parents, the risk to subsequent sibs is $6 \%$ (brothers $1 \%$, sisters $11 \%$ ); with an affected $\mathrm{CDH}$ parent, the

CONGENITAL DISLOCATION OF THE HIP. AFFECTED SIBS OF INDEX PATIENTS, DIVIDED BY SOCIAL CLASS

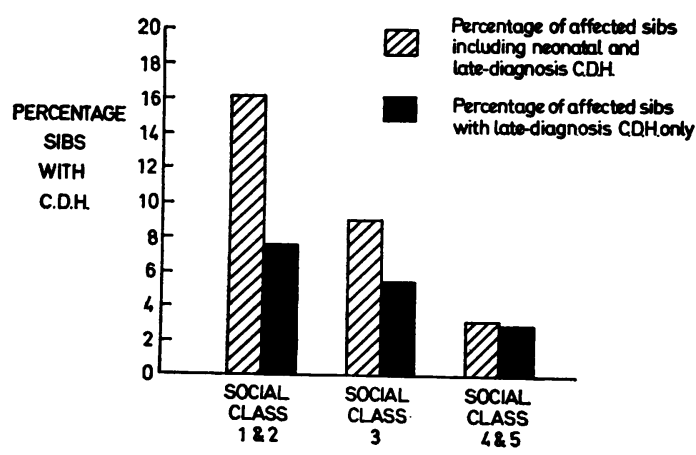

FIG. 1. The figure shows the proportions of affected sibs with neonatal and late-diagnosis $\mathrm{CDH}$, divided by social class, and illustrates the preponderance of $\mathrm{CDH}$ in the higher income groups. 
risk for a child is $12 \%$ (sons $6 \%$, daughters $17 \%$ ); with an affected $\mathrm{CDH}$ parent and one $\mathrm{CDH}$ child, the risk to a second child is $36 \%$.

The figures are higher than have been quoted in previous surveys, but include a large number of neonatal cases that in previous years would not have been recognized and would have spontaneously recovered. In view of the social class effect found, 'risk' figures are higher for classes 1 and 2, and lower for 4 and 5. Numbers are only sufficient to calculate for sibs as follows:

Social classes 1 and 2, the risk to sibs is $-16.2 \%$ $(7 \cdot 5 \%)$

Social class 3, the risk to sibs is- $8.9 \%(5.3 \%)$

Social classes, 4 and 5 the risk to sibs is- $3.0 \%$ $(2 \cdot 8 \%)$

(The figures in brackets refer to affected sibs with late-diagnosis $\mathrm{CDH}$ only.)

\section{Summary of Clinical Investigations*}

Acetabular dysplasia. Shallowness of the acetabulum invariably accompanies late-diagnosis $\mathrm{CDH}$, and the question is whether this is a primary growth defect or merely a result of the dislocated head of femur failing to stimulate growth in the socket. Faber (1937) mentioned acetabular dysplasia as a possible factor in $\mathrm{CDH}$. Wilkinson and Carter (1960) measured the 'normal' hip in unilateral $\mathrm{CDH}$ cases and found it was frequently dysplastic. In this survey measurements of the acetabulum in the $\mathrm{CDH}$ patients themselves were not found to be meaningful, as many children were not fully grown and radiographic measurement of an incompletely ossified acetabulum proved to be unsatisfactory. Measurement of the allegedly 'normal' hip in unilateral cases was also found unsatisfactory, probably because most of these hips had been subjected over a period of years to considerable disturbance by immobilization and plaster fixation during treatment of the dislocated side. It is believed that adequate radiographic measurement of the acetabulum is only possible in adults, and figures for the parents of 162 index patients in this survey were compared with a control series. It was found that the apparently normal parents of the late-diagnosis $\mathrm{CDH}$ patients had a significantly shallower acetabulum than the control group. The figures for parents of the neonatal group showed the same trend, but did not reach a significant level (Fig. 2).

Familial joint laxity. There have been previous reports of excessive joint laxity in $\mathrm{CDH}$,

\footnotetext{
* Details are reported in another paper (Wynne-Davies, 1970).
}

ACETABULAR DYSPLASIA IN CONTROLS AND CDH PARENTS C/E ANGLE - AGE CORRECTED SCORES (Both hips)

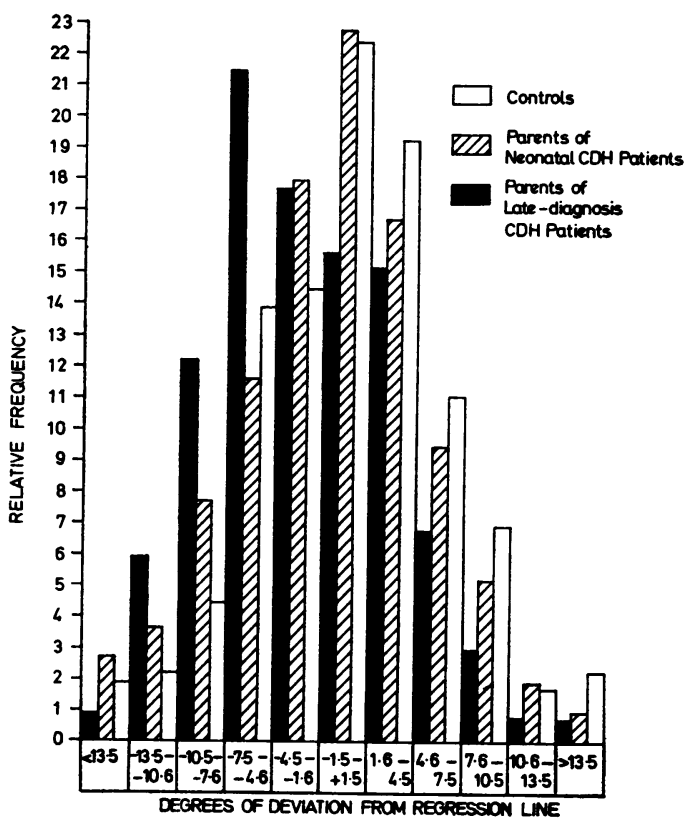

FIG. 2. Radiographic measurement of the acetabulum was made using the $\mathrm{CE}$ angle. This is obtained by joining the central points of the left and right femoral heads (which are spherical); erecting a perpendicular, and drawing a line from the centre to the edge of the acetabulum. The angle between is the $\mathrm{CE}$ angle and is a measure of the coverage of the femoral head and of the depth of the acetabulum. The angle varies on left and right sides, and in males and females, also it increases gradually throughout adult life. The histogram shows age-corrected scores for controls, and the parents of neonatal and late-diagnosis $\mathrm{CDH}$ patients. The latter have a significantly shallower acetabulum than the controls. (For details see WynneDavies, 1970).

thought to be due to an anomaly of oestrogen metabolism (Andrén and Borglin, 1961), or to familial joint laxity (Carter and Wilkinson, 1964a). In a previous study from this centre (Thieme et al., 1968), it was not found possible to confirm an anomaly of oestrogen metabolism, but this current survey did confirm the presence of excessive joint laxity both in the patients and in their first degree relatives (Fig. 3 and 4). This was particularly a feature of the neonatal CDH group. It was also found in the joint laxity control survey of normal children, that under the age of 2 years (but not over) there was a social class effect, with more laxjointed children in classes 1 and 2 than expected (significant at the 5\% level, $\chi_{(1)}^{2}=4 \cdot 1$ ).

There was further evidence for some connective tissue disturbance in both the patients and their 

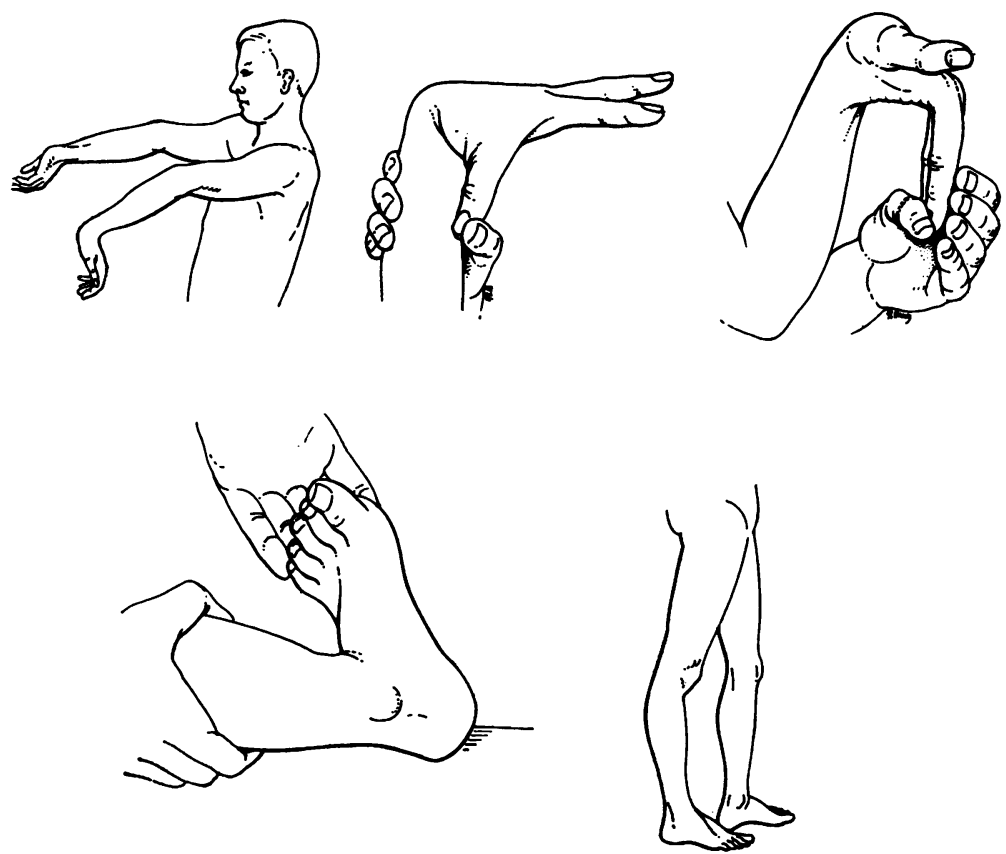

Fig. 3. This illustrates the amount of joint laxity regarded as excessive: elbows and knees extended beyond 180 degrees, the thumb touching the forearm on flexing the wrist, the fingers parallel to the forearm in extending the wrist and metacarpo-phalangeal joints, and the foot dorsiflexed to 45 degrees or less. If three of the five pairs of joints examined in any one individual showed this degree of laxity it was taken as positive.

JOINT LAXITY IN CONTROLS, C.D.H. PATIENTS AND THEIR 1ST DEGREE RELATIVES

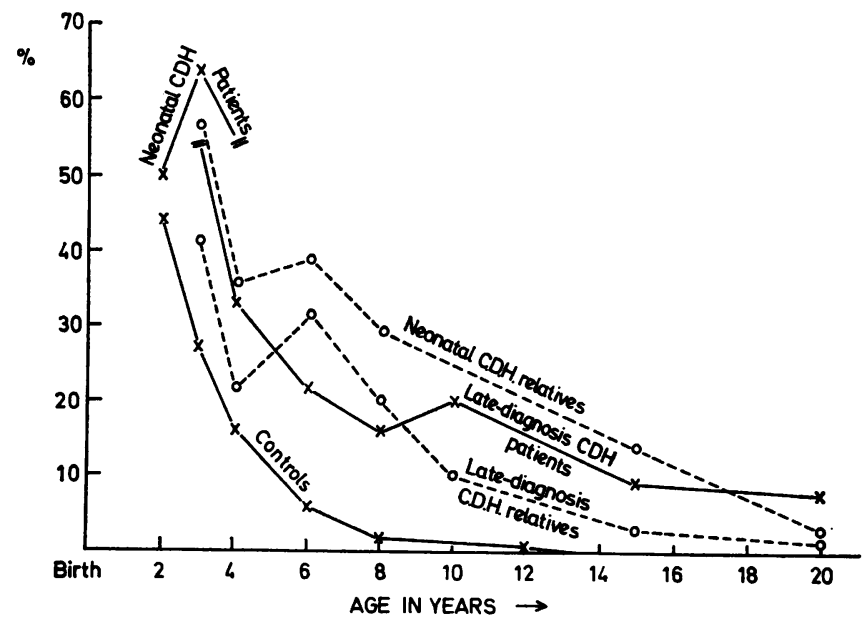

FIG. 4. The graph shows the percentage of individuals in each group examined who had excessive joint laxity. It is based on the examination of 192 neonatal and 397 late-diagnosis CDH patients, 1897 of their first degree relatives, and 3354 controls. 
relatives, in their associated anomalies. Herniae were particularly common, and there were rather more cases of club-foot and idiopathic scoliosis than expected. Other common congenital malformations occurred no more frequently than would be expected in any random survey.

\section{Discussion and Conclusions}

Environmental factors. The findings of this survey confirm others in noting an excess of firstborn children, which is independent of a maternal age effect (Record and Edwards, 1958; Woolf, Koehn, and Coleman, 1968). An increased number of breech presentations or versions has also been reported in many other surveys (Muller and Seddon, 1953; Record and Edwards, 1958). It is known that this presentation is particularly common in primiparae (whether the child has $\mathrm{CDH}$ or not) and some of the parity effect may thus be accounted for. However, there was still an excess of first-born children even after excluding breech births.

$\mathrm{CDH}$ is commoner in the winter months, and again this has been reported in other surveys (Record and Edwards, 1958; Woolf et al., 1968). In many cases this is probably related to the fact that the child is kept more tightly wrapped in the winter and the hips forced into extension. Thus a hip which would reduce itself were the child allowed to kick, is maintained out of joint and then secondary acetabular dysplasia develops. This explanation, however, cannot account for the increase of winter $\mathrm{CDH}$ noted by direct examination of the neonate during the first few days of life, and some additional factor must be acting.

The social class effect noted in the neonatal CDH group and in the joint laxity control survey has not previously been described. It could be argued that upper class families look more carefully at their children and thus larger numbers of children with neonatal $\mathrm{CDH}$ are diagnosed, but the great majority of Edinburgh births are institutional, and it is on routine examination in the maternity hospitals that the diagnosis is made. Moreover, it is probable in this country that the children of the lower social classes are in fact subjected to more frequent and searching medical examinations than the higher income groups. The effect has not previously been observed because though neonatal $\mathrm{CDH}$ is commoner in social classes 1 and 2, it is this particular type that in the past mostly corrected itself and has therefore not been included in earlier surveys. This point has been discussed under 'environmental factors', but it could also have a genetic basis.
Genetic factors.

Family incidence. There were too few twins in this survey for any conclusions to be drawn from the figures, but a large twin survey was reported by Idelberger (1951) in which 10 of 29 monozygotic twins were concordant (35\%) and only 3 of 109 dizygotic twins (3\%). These figures will certainly relate only to late-diagnosis $\mathrm{CDH}$. Kambara and Sasakawa (1954) reported 27 twin pairs from Japan, in which 15 of 21 'monochorionic' twins were concordant and 3 of 6 'bi-ovular' were concordant. It is not known if this was a complete survey of the area. It is clear that $M Z$ twins are not invariably concordant, but they are so more frequently than DZ twins, indicating a part genetic and part environmental aetiology.

The proportions of affected first degree relatives are significantly in excess of the expected figures for the normal population, though it is noted that the figures for affected parents $(0.8 \%)$ is low compared with those for sibs and children. This results partly from the absence of neonatal diagnosis in their generation, but probably also from the fact that fewer $\mathrm{CDH}$ patients than normal individuals marry. In the past, treatment of this deformity has often been unsatisfactory or not even attempted, and patients were left with deformity and an ugly limp. It was not possible to obtain accurate figures of the total number of married and unmarried $\mathrm{CDH}$ women, since it is clearly more difficult to trace those who have married and changed their names, and the survey probably includes an unduly high proportion of single women. There were only eight men in the survey over the age of 20 years (20-27 years), one was married.

There were approximately equal numbers of affected sibs and children (13 and 12\%) and though the incidence in parents was less than this, it was still significantly in excess of the expected figure for the general population. The pattern of inheritance on the over-all figures for first degree relatives could therefore be dominance of reduced penetrance, or polygenic.

There were more affected second degree relatives on the maternal than the paternal sides of the family, but this probably just reflects a greater knowledge on the mother's part of events in preceding generations on her own side of the family. No such effect was seen among third degree relatives (first cousins), who were mostly contemporary with the index patients and for whom up-to-date information would more readily be available. The rapid fall in incidence from about $12 \%$ affected sibs and children to $1.4 \%$ affected nephews and nieces (the second degree relatives for whom information is likely to be 
complete) and then to $0.3 \%$ affected first cousins (the normal population incidence), indicates polygenic rather than dominant inheritance (Carter, 1969).

Inheritance of acetabular dysplasia. The measurements for acetabular dysplasia were normally distributed and it is probable (as implied by Record and Edwards, 1958) that the configuration of the acetabulum is inherited as a multiple gene system. That being so, one would expect that the more severe the degree of dysplasia in the parents, the more relatives would be affected with $\mathrm{CDH}$. This did prove to be the case, and figures for affected sibs, divided according to the severity of acetabular dysplasia in parents, are shown in Table IX. It is thought, therefore, that acetabular dysplasia must be a primary genetic disorder of polygenic inheritance.

\section{TABLE IX}

ACETABULAR DYSPLASIA

(Sibs with CDH grouped according to severity of acetabular dysplasia or frank dislocation in parent)

\begin{tabular}{c|c|c|c}
\hline & $\begin{array}{c}\text { Mild } \\
\text { One Parent 1SD } \\
\text { From Mean }\end{array}$ & $\begin{array}{c}\text { Moderate } \\
\text { One Parent 2SD } \\
\text { From Mean or } \\
\text { Two Parents 1SD } \\
\text { Or More From } \\
\text { Mean }\end{array}$ & $\begin{array}{c}\text { Severe } \\
\text { Parent Dislocated }\end{array}$ \\
\hline $\begin{array}{c}\text { Affected } \\
\text { sibs }\end{array}$ & $\begin{array}{c}42 \text { Index Cases } \\
(8.5 \%)\end{array}$ & $\begin{array}{c}\text { 42 Index Cases } \\
(18.6 \%)\end{array}$ & 9 Index Cases \\
\hline
\end{tabular}

It was interesting to note on comparing the group in which parents had acetabular dysplasia (84) with that in which the parents' $x$-rays were normal (78), that the former had lost certain 'environmental' aspects of CDH. There was no excess of first-born children, and no excess of winter births. Other differences showed in the sex ratio which was now 0.5 and the much greater frequency of bilateral cases ( $74 \%$ compared with $32 \%$ ).

Inheritance of joint laxity. The measurement of excessive joint laxity is not so precise as measurement of the acetabulum, but since lax joints were demonstrable not only in the index patients, but in parents, sibs, and children in significantly greater numbers than in a control survey, it is thought that this must be one aetiological factor in $\mathrm{CDH}$. It is difficult to establish the exact numbers of affected families because joint laxity diminishes with age. It was often associated with other connective tissue defects, such as herniae (cf. Marfan's syndrome of dominant inheritance), but the age of appearance of these is very variable. However, in this survey a connective tissue disorder did occur in a high proportion of both sexes and all generations, and the inheritance may well be dominant. There have been families reported in the literature in which excessive joint laxity appears to be of clear dominant inheritance (Carter and Sweetnam, 1960).

Thus, it is probable that there are two independent gene systems in CDH (as suggested by Carter and Wilkinson, 1964b). One concerns the development of the acetabulum and is a polygenic system. In the past this has contributed to a high proportion of late-diagnosis $\mathrm{CDH}$. The other concerns the laxity of the capsule round the hip joint (as well as the capsules of other joints), contributes to the great majority of neonatal $\mathrm{CDH}$, and is likely to be of dominant inheritance. In the past many of these cases corrected themselves and went unnoticed. Those that remained unreduced would have developed secondary acetabular dysplasia and in due course presented as late-diagnosis $\mathrm{CDH}$. Any group of neonatal CDH patients will contain both aetiologies, though a preponderance (perhaps $80 \%$ ) of the joint laxity type, and any group of latediagnosis $\mathrm{CDH}$ patients will contain both aetiologies, but a preponderance of the primary acetabular dysplasia type.

It must also be noted that these traits are quite common in the general population, and thus some patients will have both defects. It is, unfortunately, not possible to be sure how many, because the joint laxity group cannot be clearly defined and acetabular dysplasia can only be measured with certainty in the parents. However, in the few families in which it was clear that both defects were present, there appeared to be an increased risk of CDH developing.

Falconer (1965) has developed a method for estimating the relative importance of heredity and environment in quasi-continuous traits, using data consisting of the incidence of the disorder in first degree relatives and in the general population. The correlation between relatives in respect of 'liability' to the disorder can be calculated, and from this the heritability can be estimated. It seems clear that there are two independent gene systems in $\mathrm{CDH}$, though it is not always possible (clinically) to separate them. However, a preponderance of latediagnosis $\mathrm{CDH}$ appears to be of the acetabular dysplasia type. Thus, assuming a population incidence of 1 per 1,000 , and noting the proportion of affected relatives to be 64 of $1,777(3.6 \%)$, the heritability is found to be nearly $80 \%$. A preponderance of neonatal $\mathrm{CDH}$ appears to be of the joint laxity type. Here, the population incidence is taken as 4 per 1000 , the proportion of affected sibs 28 of $207(13.5 \%)$, and the heritability is found to exceed $100 \%$, suggesting that single gene of dominant effect is involved in this case. However, 
these figures can only be tentative, since the two systems may act separately or together, and cannot always be identified in the individual patient.

\section{Summary}

A family study of 589 patients with congenital dislocation of the hip has been carried out, separating those in whom diagnosis was made in the neonatal period and those with a later diagnosis.

The survey confirms others in finding a family aggregation of cases, an increased number of breech births, a preponderance of first-born children and of children born in the winter months.

There is a significant increase of patients with neonatal $\mathrm{CDH}$ in social classes 1 and 2 (the higher income groups).

Evidence is presented indicating that two gene systems are acting: one relates to dysplasia of the acetabulum and is polygenic, and the other to laxity of the capsule round the hip joint, and is probably dominant.

Both traits may be present separately or together, but there is a preponderance of the joint laxity type in neonatal $\mathrm{CDH}$ and of the acetabular dysplasia type in late-diagnosis $\mathrm{CDH}$.

I am much indebted to Mr. G. P. Mitchell, Princess Margaret Rose Orthopaedic Hospital, Edinburgh, and Mr. N. J. Blockey, Royal Hospital for Sick Children, Glasgow, for permission to examine their patients and for access to case records. Acknowledgement and thanks are also due to Miss P. Dugard of the Department of Statistics, University of Edinburgh, to Dr. Norman Dean, formerly in charge of the Edinburgh Register of Congenital Malformations, and to Dr. H. Cameron and Dr. D. Smith for carrying out much of the family visiting. Fig. 2, 3, and 4 are published by permission of the publishers of the fournal of Bone and foint Surgery.

\section{REFERENCES}

Andrén, L., and Borglin, N. E. (1961). Disturbed urinary excretion pattern of oestrogens in newborns with congenital dislocation of the hip. I. The excretion of oestrogen during the first few days of life. Acta Endocrinologica, 37, 423-426.
Barlow, T. G. (1962). Early diagnosis and treatment of congenital dislocation of the hip. Fournal of Bone and foint Surgery, 44B, 292-301.

Carter, C. O. (1969). Genetics of common disorders. British Medical Bulletin, 25, 52-57.

- (1970). Counselling and Prognosis in Medical Genetics. Ed. by A. G. Motulsky, Hoeber, New York. In press.

, and Sweetnam, R. (1960). Recurrent dislocation of the patella and of the shoulder. Fournal of Bone and foint Surgery, 42B, 721727.

-, and Wilkinson, J. (1964a). Persistent joint laxity and congenital dislocation of the hip. Fournal of Bone and foint Surgery, 46B, 40-45.

- and (1964b). Genetic and environmental factors in the etiology of congenital dislocation of the hip. Clinical Orthopaedics and Related Research, 33, 119-128.

Edinburgh Congenital Malformations Register (1964-1967).*

Faber, A. (1937). Erbbiologische Untersuchungen über die Anlage zur angeborenen Hüftverrenkung. Zeitschrift für Orthopädie und ihre Grenzgebeite, 66, 140-166.

Falconer, D. S. (1965). The inheritance of liability to specific diseases, estimated from the incidence among relatives. Annals of Human Genetics, 29, 51-76.

Finlay, H. V. L., Maudsley, R. H., and Busfield, P. I. (1967). Dislocatable hip and dislocated hip in the newborn infant. British Medical Fournal, 4, 377-381.

Idelberger, K. (1951). Der Erbpathologie der sogennanten angeborenen Heift vervenkung. Urban and Schwarzenberg, Munich.

Kambara, H., and Sasakawa, Y. (1954). On twins with congenital dislocation of the hip. Fournal of Bone and foint Surgery, 36A, 186-187.

McIntosh, R., Merritt, K. K., Richards, M. R., Samuels, M. H., and Bellows, M. T. (1954). The incidence of congenital malformations: a study of 5964 pregnancies. Pediatrics, 14, 505-522.

Muller, G. M., and Seddon, H. J. (1953). Late results of treatment of congenital dislocation of the hip. Fournal of Bone and foint Surgery, 35B, 342-362.

Nelson, M. A. (1966). Early diagnosis of congenital dislocation of the hip. Fournal of Bone and foint Surgery, 48B, 388.

Record, R. G., and Edwards, J. H. (1958). Environmental influences related to the aetiology of congenital dislocation of the hip. British fournal of Preventive and Social Medicine, 12, 8-22.

Registrar General for Scotland (1939-1967). Annual Reports. H.M.S.O., Edinburgh.

Thieme, W. T., Wynne-Davies, R., Blair, H. A. F., Bell, E. T., and Loraine, J. A. (1968). Clinical examination and urinary oestrogen assays in newborn children with congenital dislocation of the hip. fournal of Bone and foint Surgery, 50B, 546-550.

Wilkinson, J., and Carter, C. (1960). Congenital dislocation of the hip: the results of conservative treatment. Fournal of Bone and Foint Surgery, 42B, 669-688.

Wilson, D. W. (1964). Congenital dislocation of the hip. Fournal of Bone and foint Surgery, 46B, 163.

Woolf, C. M., Koehn, J. H., and Coleman, S. S. (1968). Congenital hip disease in Utah: the influence of genetic and nongenetic factors. American fournal of Human Genetics, 20, 430-439.

Wynne-Davies, R. (1970). Acetabular dysplasia and familial joint laxity: two aetiological factors in congenital dislocation of the hip. fournal of Bone and foint Surgery, in the press.

* Held at Department of Social Medicine, University of Edinburgh. 


\section{Appendix}

\section{Edinburgh/Glasgow CDH Survey}

$\mathrm{M}$, male; $\mathrm{F}$, female (italics indicate patients with $\mathrm{CDH}$ ); $\mathrm{n}$, neonatal diagnosis $\mathrm{CDH}$; l, late diagnosis $\mathrm{CDH}$; m, miscarriage; sb, stillbirth *,index patient; [ ], twins.

e.g. ${ }^{*} F l$, index, female, late diagnosis.

\begin{tabular}{|c|c|c|c|}
\hline \multirow{2}{*}{$\begin{array}{l}\text { Serial } \\
\text { No. }\end{array}$} & \multirow{2}{*}{ Sibship } & \multicolumn{2}{|c|}{ Date of Birth } \\
\hline & & Father & Mother \\
\hline $\left.\begin{array}{l}1 \\
2\end{array}\right\}$ & $M 11 / 61 ;\left[F_{n} * F n\right] 10 / 64$ & 1930 & 1938 \\
\hline $\begin{array}{c}3 \\
4 \\
5 \\
6 \\
7 \\
8 \\
9 \\
107\end{array}$ & 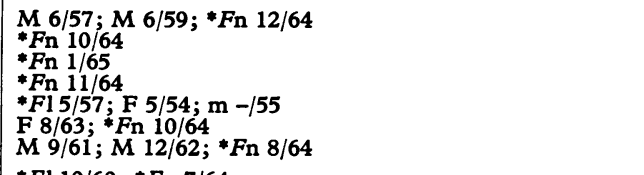 & $\begin{array}{l}1926 \\
1929 \\
\text { NK } \\
1934 \\
1926 \\
1936 \\
1937\end{array}$ & $\begin{array}{l}1935 \\
1933 \\
1941 \\
1936 \\
1926 \\
1942 \\
1941\end{array}$ \\
\hline $\left.\begin{array}{l}10 \\
11\end{array}\right\}$ & $* F 110 / 60 ; * F n 7 / 64$ & 1935 & 1937 \\
\hline $\left.\begin{array}{l}12 \\
13\end{array}\right\}$ & ${ }^{*} M \mathrm{Mn} 11 / 62 ;{ }^{*} F_{\mathrm{n}} 11 / 64$ & 1927 & 1926 \\
\hline $\begin{array}{l}14 \\
15 \\
16 \\
17 \\
18 \\
19\end{array}$ & $\begin{array}{l}\text { M } 2 / 59 ; * F n ~ 8 / 63 \\
\text { F } 5 / 62 ; *^{*} F \mathrm{n} 1 / 64 \\
{ }^{*} F \mathrm{n} 12 / 64 \\
{ }^{*} F 112 / 53 \\
\mathrm{M} 10 / 46 ; \mathrm{m} 6 / 48 ;{ }^{*} F 11 / 51 ; M 1 / 56 \\
\mathrm{~m}-/ 57 ; \mathrm{m}-/ 58 ; M 4 / 59 ; *^{*} \mathrm{Fn} 3 / 64\end{array}$ & $\begin{array}{l}1920 \\
1927 \\
1946 \\
1916 \\
1906 \\
1931\end{array}$ & $\begin{array}{l}1929 \\
1929 \\
1943 \\
1919 \\
1914 \\
1930\end{array}$ \\
\hline $\left.\begin{array}{l}20 \\
21\end{array}\right\}$ & ${ }^{*} M 11 / 63 ;{ }^{*} F \mathrm{n} 10 / 64$ & 1939 & 1940 \\
\hline $\begin{array}{l}22 \\
23 \\
24 \\
25 \\
26 \\
27\end{array}$ & $\begin{array}{l}{ }^{*} F 112 / 58 ; \mathrm{F} 8 / 62 \\
\mathrm{~F} 11 / 42 ; \mathrm{F} / 50 ; \mathrm{M} 11 / 54 ; \mathrm{m}-/ 57 ;{ }^{*} M 110 / 59 \\
{ }^{*} F 110 / 55 ; \mathrm{F} 4 / 58 \\
*^{F 1} 1 / 59 ; \mathrm{F} 12 / 61 \\
\text { F } 6 / 62 ; *{ }^{*} 1 / 65 \\
\text { m } 10 / 63 ;{ }^{*} \text { Fn } 1 / 65\end{array}$ & $\begin{array}{l}1931 \\
1922 \\
1926 \\
1933 \\
1931 \\
1933\end{array}$ & $\begin{array}{l}1928 \\
1921 \\
1931 \\
1937 \\
1936 \\
1940\end{array}$ \\
\hline $\left.\begin{array}{l}28 \\
29\end{array}\right\}$ & ${ }^{*} F_{\mathrm{n}} 9 / 62 ;{ }^{*} F_{\mathrm{n}} 12 / 64 ; \mathrm{M} 12 / 66$ & 1942 & 1943 \\
\hline $\begin{array}{l}30 \\
31 \\
32 \\
33 \\
34 \\
35 \\
36\end{array}$ & 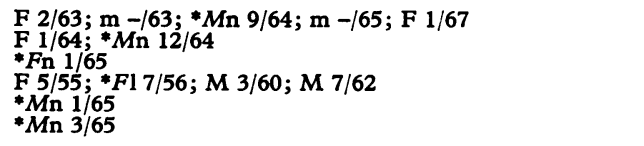 & $\begin{array}{l}1936 \\
1944 \\
1938 \\
1932 \\
1937 \\
1939\end{array}$ & $\begin{array}{l}1940 \\
1946 \\
1939 \\
1931 \\
1937 \\
1937\end{array}$ \\
\hline $\left.\begin{array}{l}36 \\
37\end{array}\right\}$ & ${ }^{*} M n$ 6/63; ${ }^{*} M n 3 / 65$ & 1932 & 1939 \\
\hline $\begin{array}{l}38 \\
39 \\
40 \\
41 \\
42 \\
43 \\
44 \\
45 \\
46 \\
47\end{array}$ & 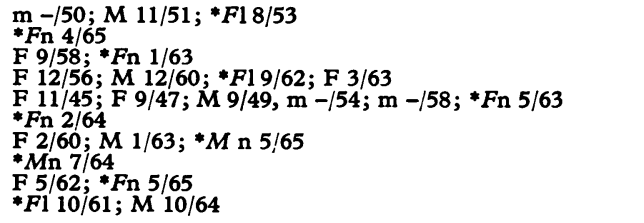 & $\begin{array}{l}1926 \\
1936 \\
1928 \\
1925 \\
1921 \\
1936 \\
1933 \\
1936 \\
1937 \\
1934\end{array}$ & $\begin{array}{l}1928 \\
1938 \\
1929 \\
1931 \\
1923 \\
1938 \\
1942 \\
1939 \\
1935 \\
1937\end{array}$ \\
\hline $\left.\begin{array}{r}48 \\
157\end{array}\right\}$ & ${ }^{*} F 14 / 58 ; M 7 / 60 ; * F 112 / 65$ & 1932 & 1932 \\
\hline 49 & m 2/64;*Fn $6 / 65$ & 1934 & 1940 \\
\hline $\left.\begin{array}{l}50 \\
51\end{array}\right\}$ & $* F 112 / 58 ; * F 13 / 65$ & 1934 & 1936 \\
\hline $\begin{array}{l}52 \\
53 \\
54 \\
55 \\
56 \\
57 \\
58 \\
59 \\
60 \\
61 \\
62\end{array}$ & 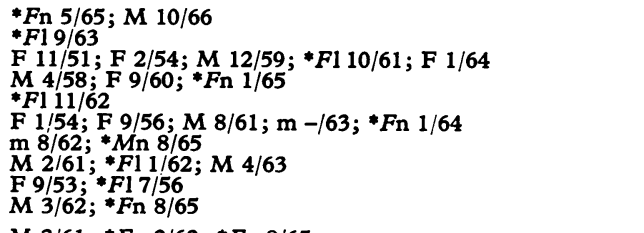 & $\begin{array}{l}1943 \\
1943 \\
1929 \\
1935 \\
1927 \\
1933 \\
1938 \\
1937 \\
1918 \\
1927\end{array}$ & $\begin{array}{l}1946 \\
1944 \\
1930 \\
1940 \\
1922 \\
1935 \\
1938 \\
1939 \\
1924 \\
1925\end{array}$ \\
\hline 62$\}$ & $\mathrm{M} 3 / 61 ; * F_{n} 2 / 62 ; * F_{n} 8 / 65$ & 1939 & 1939 \\
\hline $\left.\begin{array}{r}64 \\
65\end{array}\right\}$ & ${ }^{*} F \mathrm{n} 8 / 59 ; \mathrm{M} 9 / 60 ; \mathrm{F} 8 / 63{ }^{*} F \mathrm{n} 3 / 65$ (See 297) & 1936 & $\begin{array}{l}* 1935 \\
(\mathrm{No} .297)\end{array}$ \\
\hline $\begin{array}{l}66 \\
67 \\
68 \\
69 \\
70\end{array}$ & $\begin{array}{l}{ }^{*} F \mathrm{n} 6 / 63 \\
{ }^{*} F \mathrm{n} 8 / 65 \\
{ }^{*} F \mathrm{n} 6 / 65 \\
{ }^{*} F 112 / 63\end{array}$ & $\begin{array}{l}1938 \\
1937 \\
1945 \\
1929\end{array}$ & $\begin{array}{c}1940 \\
1939 \\
1947 \\
1938\end{array}$ \\
\hline $\left.\begin{array}{l}70 \\
71\end{array}\right\}$ & ${ }^{*} F$ n $10 / 62 ; * F 17 / 65$ & 1935 & 1928 \\
\hline $\begin{array}{l}72 \\
73 \\
74\end{array}$ & $\begin{array}{l}{ }^{*} M n 8 / 65 \\
{ }^{*} F n 6 / 65 \\
M 4 / 60 ; \text { F } 7 / 61 ;{ }^{*} M n 6 / 65\end{array}$ & $\begin{array}{l}1940 \\
1943 \\
1934\end{array}$ & $\begin{array}{l}1942 \\
1947 \\
1933\end{array}$ \\
\hline
\end{tabular}


Appendix-continued

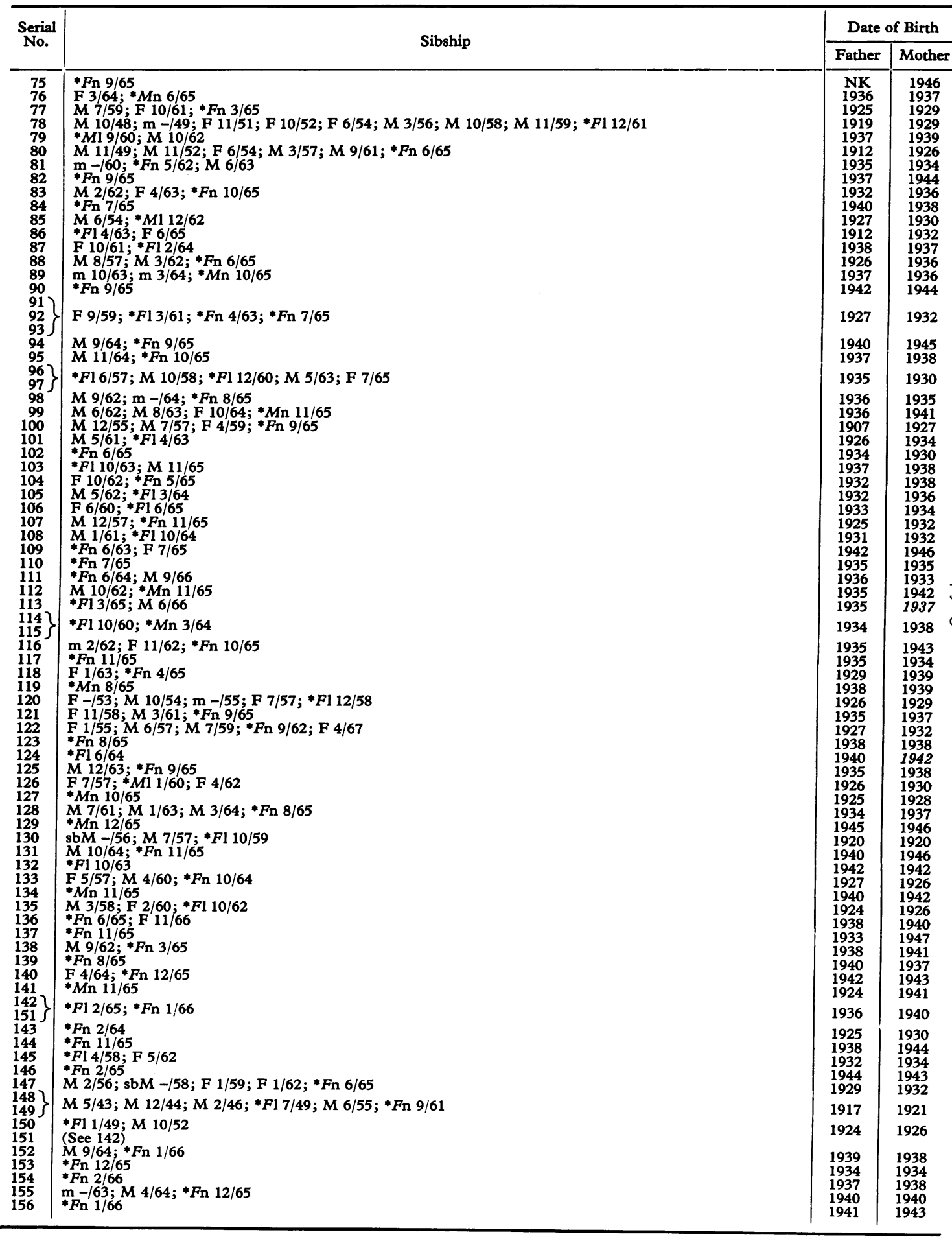


Appendix-continued

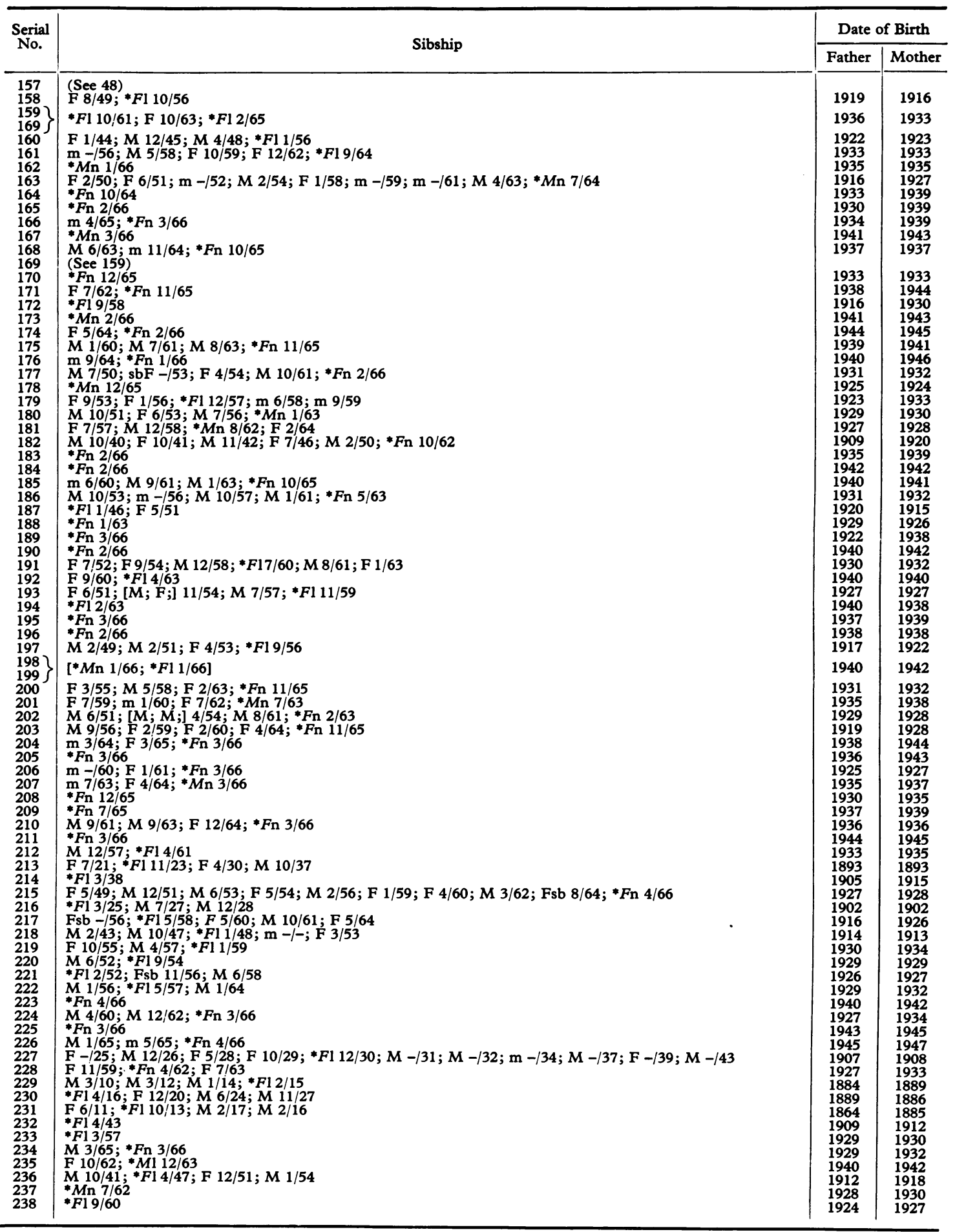


Appendix-continued

\begin{tabular}{|c|c|c|c|}
\hline \multirow{2}{*}{$\begin{array}{l}\text { Serial } \\
\text { No. }\end{array}$} & \multirow{2}{*}{ Sibship } & \multicolumn{2}{|c|}{ Date of Birth } \\
\hline & & Father & Mother \\
\hline $\begin{array}{l}239 \\
240 \\
241 \\
242 \\
243 \\
244 \\
245 \\
246 \\
247 \\
248 \\
249\end{array}$ & 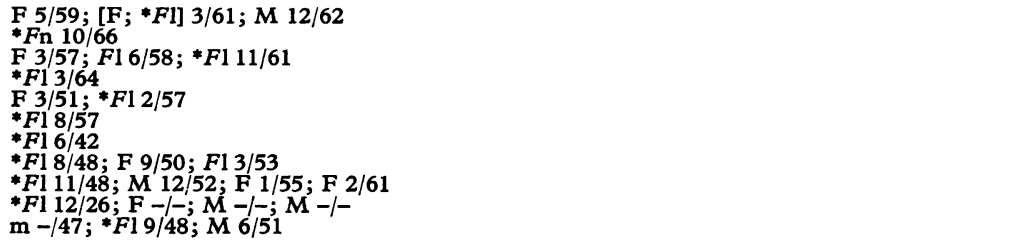 & $\begin{array}{l}1928 \\
1938 \\
1923 \\
1931 \\
1925 \\
1929 \\
1921 \\
1922 \\
1924 \\
1897 \\
1927\end{array}$ & $\begin{array}{l}1933 \\
1941 \\
1928 \\
1938 \\
1924 \\
1932 \\
1922 \\
1922 \\
1924 \\
1897 \\
1926\end{array}$ \\
\hline $\begin{array}{l}250 \\
251 \\
252 \\
253 \\
254 \\
255 \\
256 \\
257 \\
258 \\
259 \\
260 \\
261 \\
262 \\
263 \\
264 \\
265 \\
266 \\
267 \\
268 \\
269 \\
270 \\
271 \\
272 \\
273 \\
274 \\
275 \\
276 \\
277\end{array}$ & 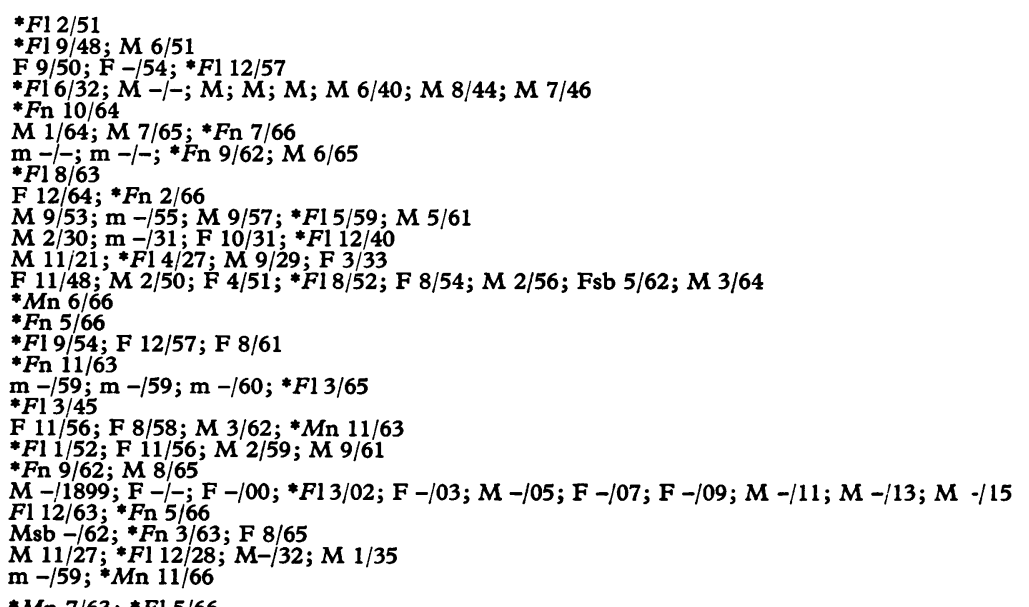 & $\begin{array}{l}1921 \\
1923 \\
1921 \\
1901 \\
1928 \\
1934 \\
1930 \\
\text { NK } \\
1943 \\
1926 \\
1901 \\
1901 \\
1930 \\
1925 \\
1946 \\
1929 \\
1939 \\
1929 \\
1917 \\
1927 \\
1925 \\
1933 \\
N K \\
1938 \\
1940 \\
1901 \\
1938\end{array}$ & 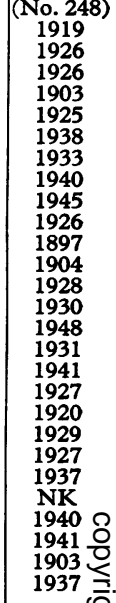 \\
\hline $\left.\begin{array}{l}277 \\
278\end{array}\right\}$ & $* M n 7 / 63 ; * F 15 / 66$ & 1935 & 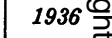 \\
\hline $\begin{array}{l}279 \\
280 \\
281 \\
282 \\
283 \\
284 \\
285 \\
286 \\
287 \\
288\end{array}$ & 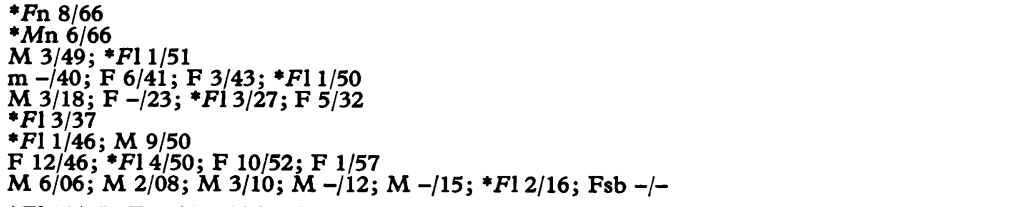 & $\begin{array}{l}1938 \\
1938 \\
1923 \\
1908 \\
1879 \\
1907 \\
1916 \\
1915 \\
\text { NK }\end{array}$ & $\begin{array}{l}1942 \\
1945 \\
1921 \\
1909 \\
1893 \\
1905 \\
1918 \\
1924 \\
\text { NK }\end{array}$ \\
\hline 288$\}$ & ${ }^{*} F 112 / 45 ; F$ n $1 / 59 ; * F 111 / 61$ & 1927 & 1931 \\
\hline 289 & M 4/53; F 7/55; M 4/58; M 1/60; *F1 7/62 & 1930 & 1933 \\
\hline $\begin{array}{l}291 \\
292 \\
293 \\
294 \\
295 \\
296 \\
297 \\
298 \\
299 \\
300 \\
301 \\
302 \\
303 \\
304 \\
305 \\
306 \\
307 \\
308 \\
309 \\
310 \\
311 \\
312 \\
313 \\
314 \\
315 \\
316 \\
317 \\
318 \\
319\end{array}$ & 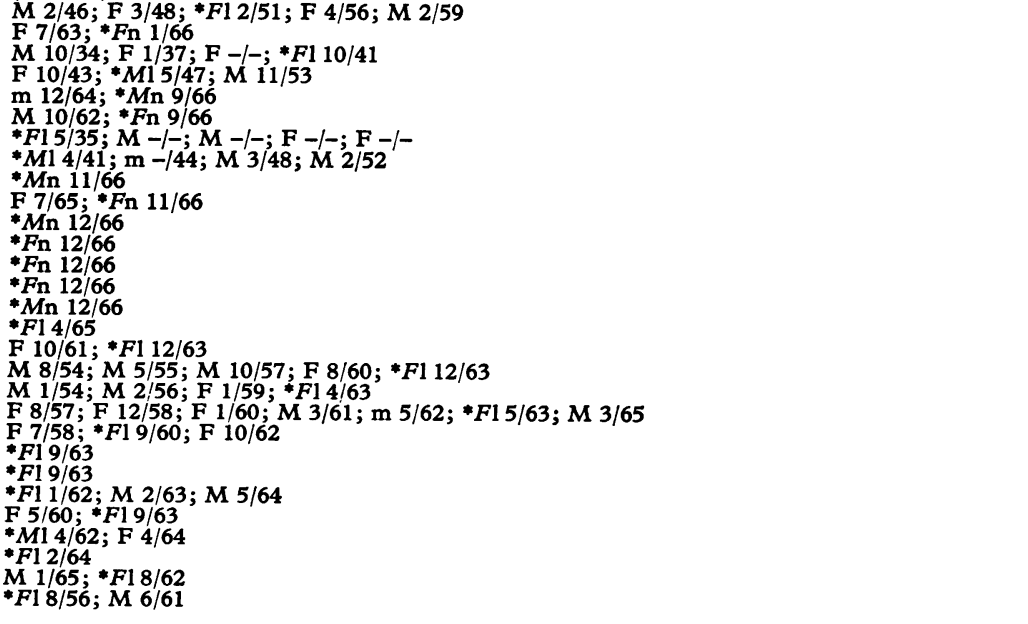 & $\begin{array}{l}1924 \\
1932 \\
1914 \\
1921 \\
1937 \\
1938 \\
1881 \\
1906 \\
1946 \\
1935 \\
1944 \\
1941 \\
1942 \\
1938 \\
1944 \\
1939 \\
1940 \\
1932 \\
1929 \\
1933 \\
1938 \\
1929 \\
1937 \\
1935 \\
1938 \\
1934 \\
1939 \\
1941 \\
1924\end{array}$ & $\begin{array}{l}1925 \\
1938 \\
1916 \\
1922 \\
1937 \\
1943 \\
1883 \\
1915 \\
1943 \\
1936 \\
1946 \\
1945 \\
1943 \\
1942 \\
1941 \\
1937 \\
1939 \\
1935 \\
1930 \\
1936 \\
1935 \\
1936 \\
1942 \\
1939 \\
1937 \\
1939 \\
1940 \\
1941 \\
1926\end{array}$ \\
\hline
\end{tabular}


Appendix-continued

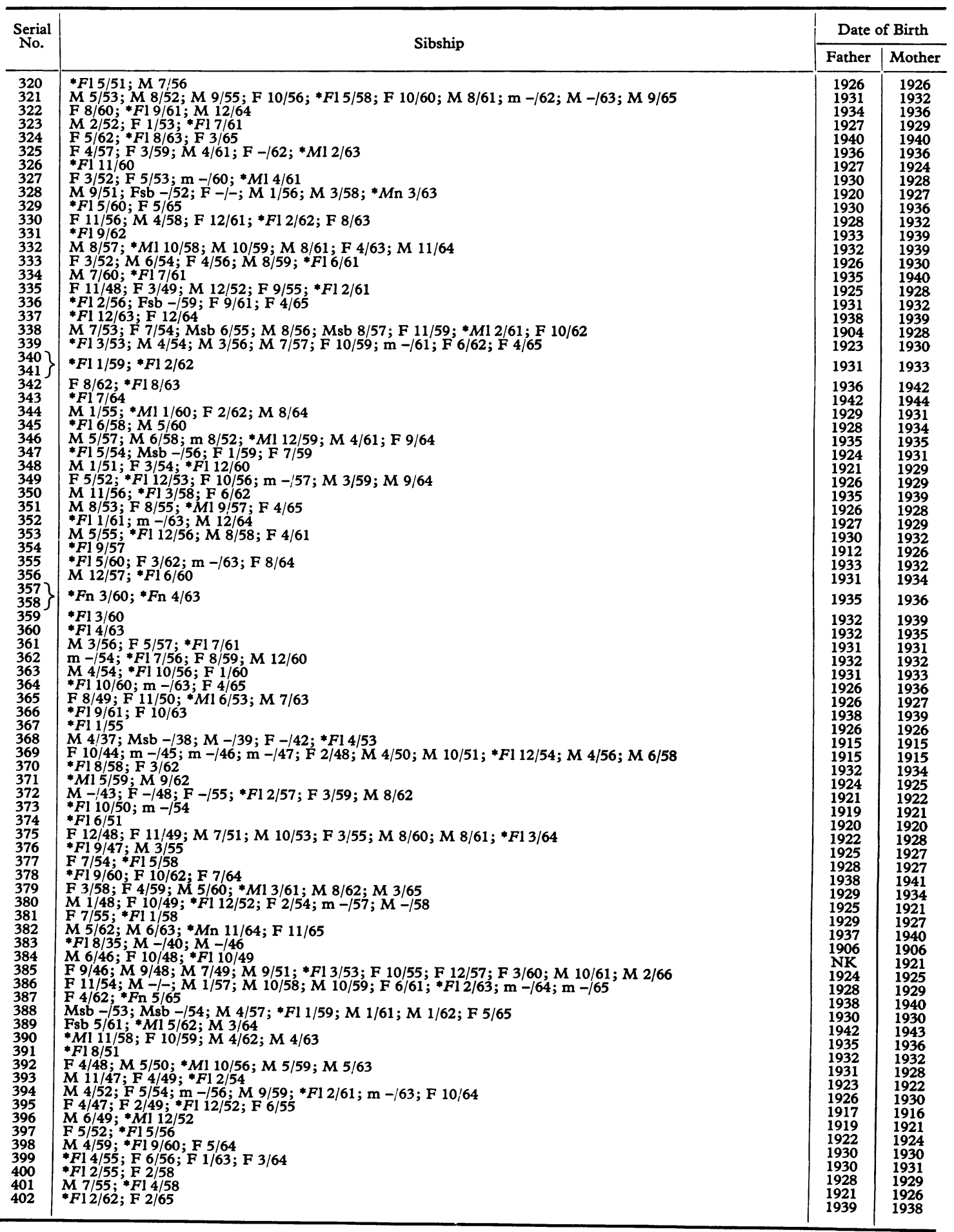


Appendix-continued

\begin{tabular}{|c|c|c|c|}
\hline \multirow{2}{*}{$\begin{array}{c}\text { Serial } \\
\text { No. }\end{array}$} & \multirow{2}{*}{ Sibship } & \multicolumn{2}{|c|}{ Date of Birth } \\
\hline & & Father & Mother \\
\hline $\begin{array}{l}403 \\
404 \\
405 \\
406 \\
407 \\
408 \\
409 \\
410 \\
411 \\
412 \\
413 \\
414\end{array}$ & 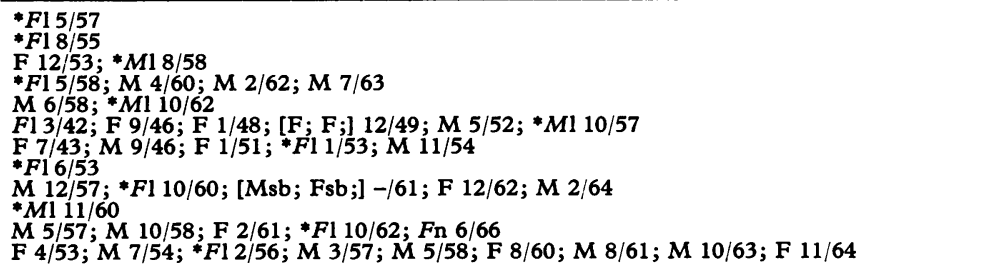 & $\begin{array}{l}1921 \\
1921 \\
1928 \\
1933 \\
1933 \\
1913 \\
1916 \\
1922 \\
1928 \\
1935 \\
1925 \\
1931\end{array}$ & $\begin{array}{l}1920 \\
1920 \\
1930 \\
1936 \\
1935 \\
1915 \\
1921 \\
1924 \\
1935 \\
1938 \\
1932 \\
1931\end{array}$ \\
\hline $\left.\begin{array}{l}415 \\
416\end{array}\right\}$ & 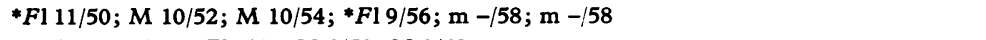 & 1925 & 1929 \\
\hline $\begin{array}{l}417 \\
418 \\
419 \\
420 \\
421 \\
422 \\
423 \\
424 \\
425\end{array}$ & 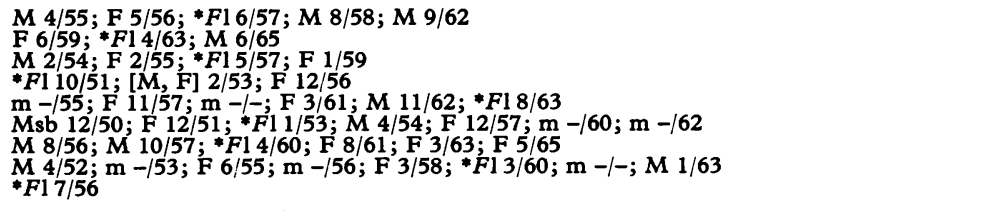 & $\begin{array}{l}1926 \\
1933 \\
1929 \\
1920 \\
1931 \\
1927 \\
1929 \\
1922 \\
1903\end{array}$ & $\begin{array}{l}1924 \\
1937 \\
1931 \\
1922 \\
1935 \\
1931 \\
1930 \\
1930 \\
1917\end{array}$ \\
\hline $\left.\begin{array}{l}426 \\
427\end{array}\right\}$ & $* F 110 / 59 ;{ }^{*} F \mathrm{n} 8 / 62 ;$ F $1 / 66$ & 1931 & 1933 \\
\hline $\begin{array}{l}428 \\
429 \\
430 \\
431 \\
432 \\
433 \\
434 \\
435 \\
436 \\
437 \\
438 \\
439 \\
440 \\
441 \\
442 \\
443\end{array}$ & 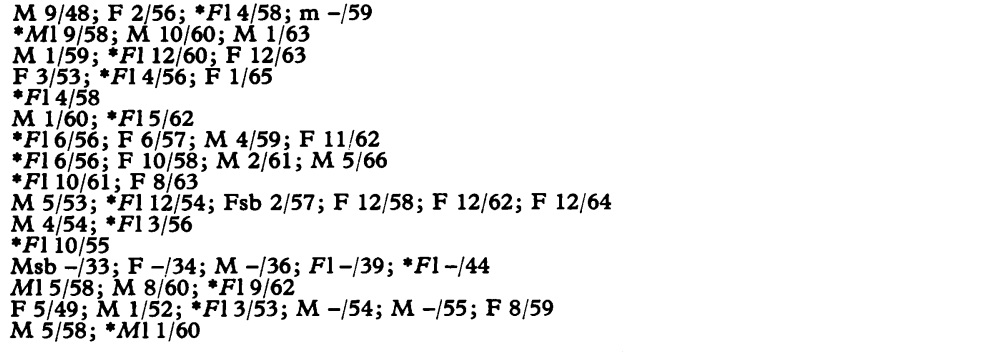 & $\begin{array}{l}1924 \\
1933 \\
1930 \\
1923 \\
1933 \\
1938 \\
1928 \\
1930 \\
1941 \\
1933 \\
1923 \\
1923 \\
1908 \\
1928 \\
1921 \\
1934\end{array}$ & $\begin{array}{l}1928 \\
1933 \\
1930 \\
1922 \\
1933 \\
1937 \\
1927 \\
1930 \\
1941 \\
1932 \\
1923 \\
1926 \\
1916 \\
1928 \\
1925 \\
1935\end{array}$ \\
\hline $\left.\begin{array}{l}444 \\
445\end{array}\right\}$ & Msb $12 / 53 ;{ }^{*} F 112 / 54 ;$ F $7 / 56 ; * F 110 / 57 ;$ Msb $1 / 59 ;$ F $7 / 62$ & 1923 & 1928 \\
\hline $\begin{array}{l}446 \\
447 \\
448 \\
449 \\
450 \\
451 \\
452 \\
453 \\
454 \\
455 \\
456 \\
457 \\
458 \\
459 \\
460 \\
461 \\
462 \\
463 \\
464\end{array}$ & 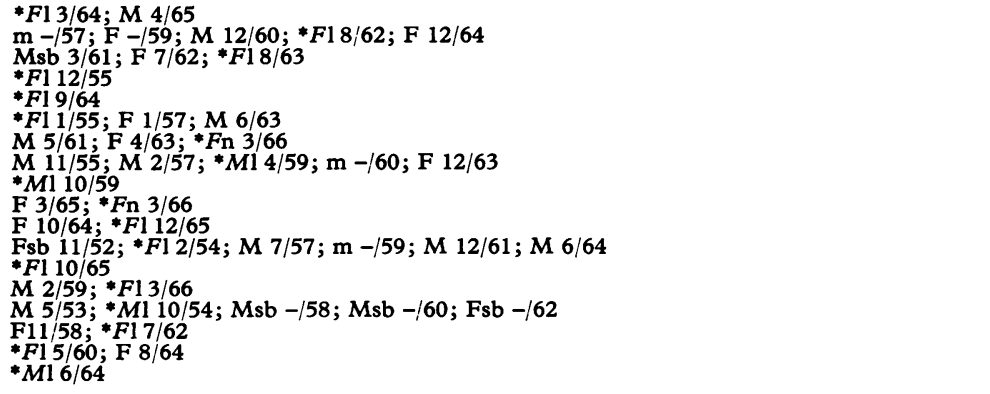 & $\begin{array}{l}1933 \\
1926 \\
1932 \\
1908 \\
1942 \\
1930 \\
1934 \\
1933 \\
1928 \\
1945 \\
1936 \\
1929 \\
1938 \\
1922 \\
1925 \\
1919 \\
1932 \\
1939\end{array}$ & $\begin{array}{l}1937 \\
1927 \\
1936 \\
1912 \\
1941 \\
1930 \\
1933 \\
1933 \\
1927 \\
1943 \\
1940 \\
1930 \\
1944 \\
1935 \\
1932 \\
1930 \\
1933 \\
1939\end{array}$ \\
\hline & ${ }^{*} M 18 / 59 ;{ }^{*} F 15 / 62$ & 1935 & 1939 \\
\hline $\begin{array}{l}466 \\
467 \\
468 \\
469 \\
470 \\
471 \\
472 \\
473 \\
474 \\
475 \\
476 \\
477 \\
478 \\
479 \\
480 \\
481 \\
482 \\
483 \\
484 \\
485\end{array}$ & 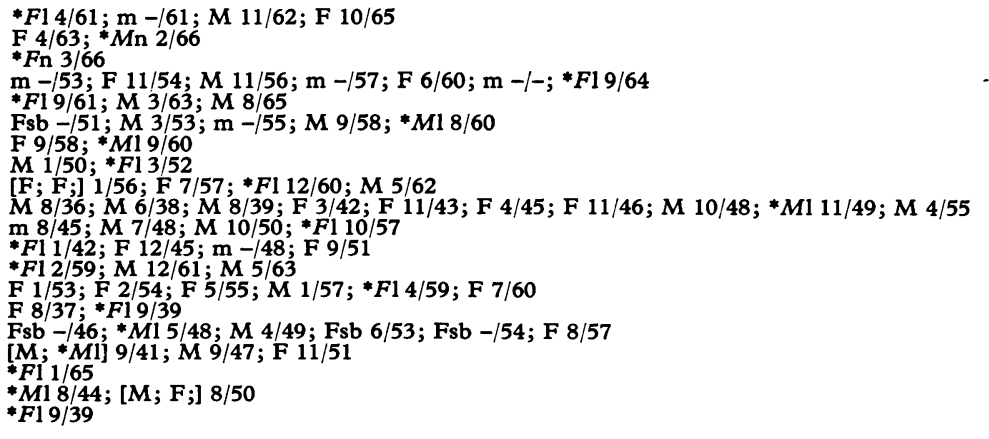 & $\begin{array}{l}1931 \\
1937 \\
1944 \\
1935 \\
1937 \\
1921 \\
1931 \\
1920 \\
1928 \\
1911 \\
1911 \\
1912 \\
1930 \\
1924 \\
1911 \\
1906 \\
1917 \\
1935 \\
1920 \\
1920\end{array}$ & $\begin{array}{l}1939 \\
1943 \\
1948 \\
1934 \\
1938 \\
1924 \\
1933 \\
1927 \\
1932 \\
1916 \\
1914 \\
1915 \\
1929 \\
1934 \\
1909 \\
1914 \\
1918 \\
1941 \\
1921 \\
1921\end{array}$ \\
\hline
\end{tabular}


Appendix-continued

\begin{tabular}{|c|c|c|c|}
\hline \multirow{2}{*}{$\begin{array}{l}\text { Serial } \\
\text { No. }\end{array}$} & \multirow{2}{*}{ Sibship } & \multicolumn{2}{|c|}{ Date of Birth } \\
\hline & & Father & Mother \\
\hline $\begin{array}{l}\mathbf{4 8 6} \\
487 \\
488 \\
489 \\
490 \\
491 \\
492 \\
493 \\
494 \\
495 \\
496 \\
497 \\
498 \\
499 \\
500 \\
501 \\
502 \\
503 \\
504 \\
505 \\
506 \\
507 \\
508 \\
509 \\
510 \\
511 \\
512 \\
513 \\
514 \\
515 \\
516 \\
517 \\
518 \\
519 \\
520 \\
521 \\
522 \\
523 \\
524 \\
525 \\
526 \\
527 \\
528 \\
529 \\
530 \\
531 \\
532 \\
533 \\
534 \\
535 \\
536 \\
537 \\
538 \\
539 \\
540 \\
541 \\
542 \\
543 \\
544 \\
545 \\
559 \\
560 \\
561 \\
562 \\
563 \\
565 \\
566 \\
567 \\
568 \\
549 \\
550 \\
552 \\
553 \\
553 \\
\end{array}$ & 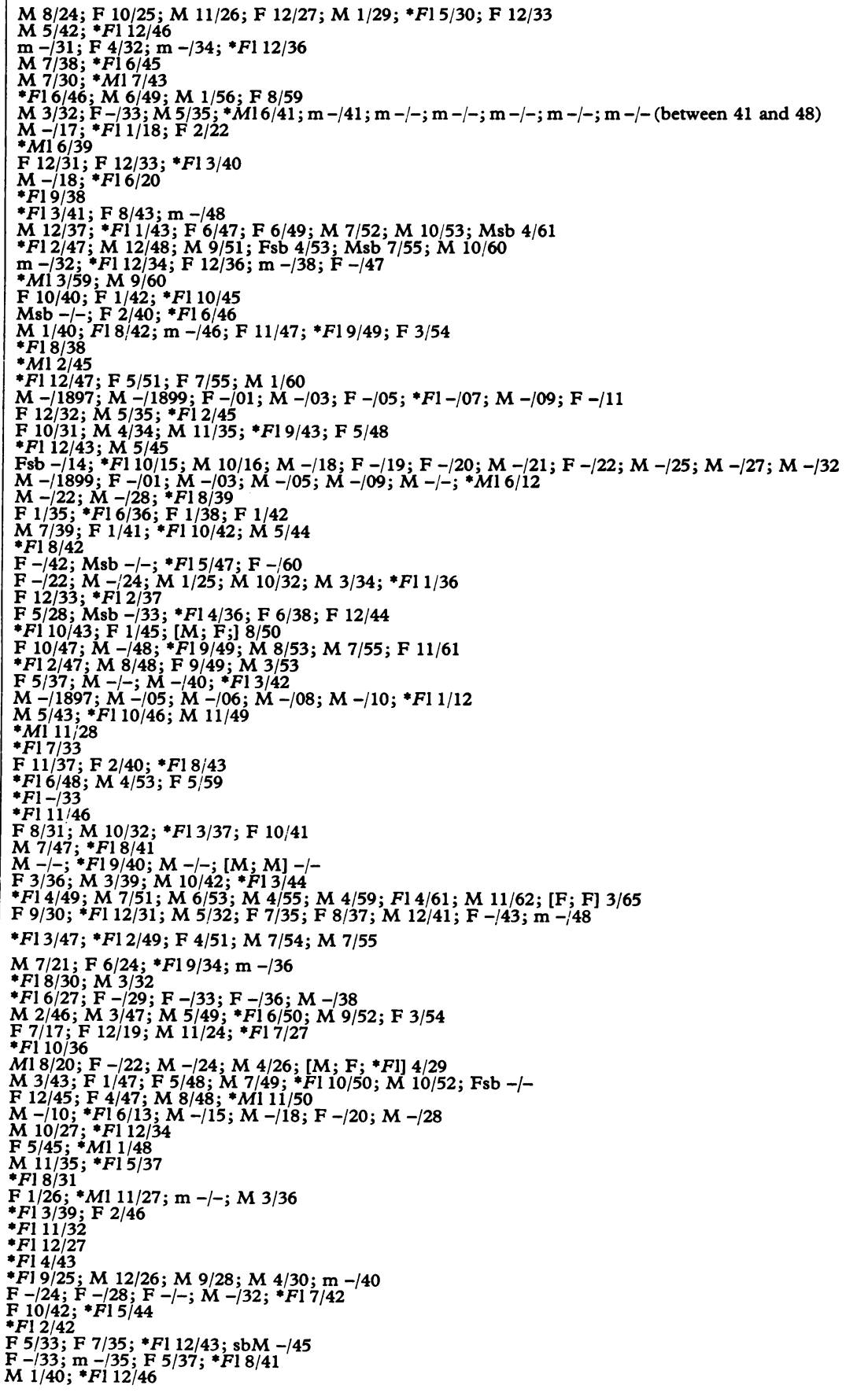 & $\begin{array}{l}1899 \\
1914 \\
1895 \\
1911 \\
1900 \\
\mathrm{NK} \\
1900 \\
\mathrm{NK} \\
\mathrm{NK} \\
1899 \\
1884 \\
1912 \\
1903 \\
1914 \\
1920 \\
1913 \\
1930 \\
1905 \\
1912 \\
1915 \\
1902 \\
1893 \\
1917 \\
1869 \\
1905 \\
1903 \\
1907 \\
1890 \\
1880 \\
1893 \\
1908 \\
1911 \\
1894 \\
1922 \\
1897 \\
1902 \\
1906 \\
1912 \\
1923 \\
1921 \\
1903 \\
\mathrm{NK} \\
1919 \\
\mathrm{NK} \\
1898 \\
1908 \\
1920 \\
1906 \\
1910 \\
1902 \\
1915 \\
\mathrm{NK} \\
1908 \\
1917 \\
1906 \\
1917 \\
\mathrm{NK} \\
1898 \\
1902 \\
1923 \\
1888 \\
1908 \\
\mathrm{NK} \\
1923 \\
1916 \\
1888 \\
1897 \\
1920 \\
1899 \\
1900 \\
1888 \\
1900 \\
1908 \\
1898 \\
1909 \\
1902 \\
1900 \\
1908 \\
\mathrm{NK} \\
\mathrm{NK} \\
1902 \\
1909 \\
\end{array}$ & $\begin{array}{l}1900 \\
1916 \\
1894 \\
1911 \\
1901 \\
1926 \\
1904 \\
\mathrm{NK} \\
\mathrm{NK} \\
1906 \\
1884 \\
1913 \\
1906 \\
1914 \\
1926 \\
1914 \\
1933 \\
1910 \\
1920 \\
1917 \\
1907 \\
1906 \\
1924 \\
1870 \\
1907 \\
1906 \\
1912 \\
1896 \\
1900 \\
1893 \\
1912 \\
1913 \\
1910 \\
1922 \\
1898 \\
1905 \\
1906 \\
1916 \\
1922 \\
1922 \\
1914 \\
\mathrm{NK} \\
1922 \\
1909 \\
1901 \\
1909 \\
1925 \\
1907 \\
1913 \\
1908 \\
1912 \\
\mathrm{NK} \\
1915 \\
1923 \\
1913 \\
1922 \\
1894 \\
1902 \\
1904 \\
1923 \\
1889 \\
1912 \\
\mathrm{NK} \\
1923 \\
1920 \\
1888 \\
1899 \\
1915 \\
1903 \\
1902 \\
1890 \\
1910 \\
1910 \\
1896 \\
1908 \\
1898 \\
1901 \\
1997 \\
1919 \\
1911 \\
1906 \\
1913 \\
\end{array}$ \\
\hline
\end{tabular}


Appendix-continued

\begin{tabular}{|c|c|c|c|}
\hline \multirow{2}{*}{$\begin{array}{l}\text { Serial } \\
\text { No. }\end{array}$} & \multirow{2}{*}{ Sibship } & \multicolumn{2}{|c|}{ Date of Birth } \\
\hline & & Father & Mother \\
\hline $\begin{array}{l}569 \\
570 \\
571 \\
572 \\
573 \\
574 \\
575 \\
576 \\
577 \\
578 \\
579\end{array}$ & 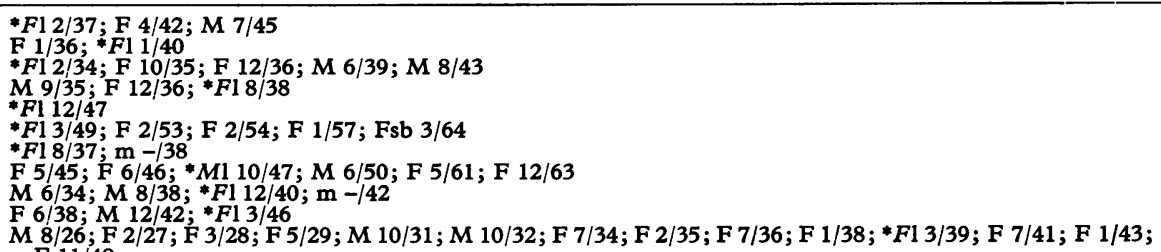 & $\begin{array}{l}1910 \\
1913 \\
1913 \\
1928 \\
1917 \\
1921 \\
1904 \\
1922 \\
1899 \\
1909\end{array}$ & $\begin{array}{l}1915 \\
1914 \\
1915 \\
1916 \\
1918 \\
1922 \\
1911 \\
1923 \\
1904 \\
1910\end{array}$ \\
\hline $\begin{array}{l}\mathbf{5 8 0} \\
\mathbf{5 8 1} \\
\mathbf{5 8 2} \\
\mathbf{5 8 3} \\
\mathbf{5 8 4} \\
\mathbf{5 8 5} \\
\mathbf{5 8 6} \\
\mathbf{5 8 7} \\
\mathbf{5 8 8} \\
\mathbf{5 8 9}\end{array}$ & 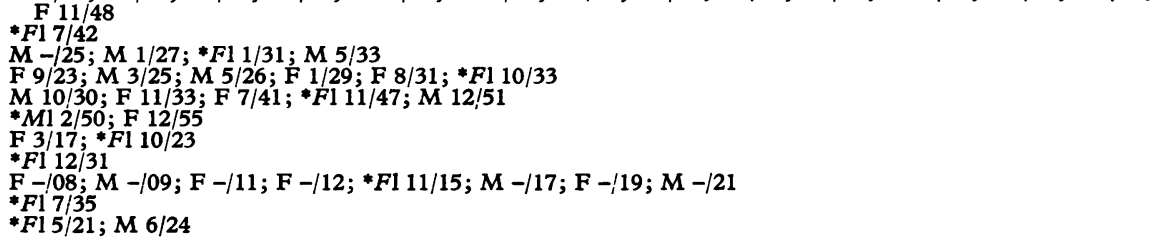 & $\begin{array}{l}1899 \\
1895 \\
1898 \\
1892 \\
1906 \\
1926 \\
1890 \\
1898 \\
1880 \\
1888 \\
1895\end{array}$ & $\begin{array}{l}1903 \\
1905 \\
1900 \\
1895 \\
1908 \\
1926 \\
1891 \\
1901 \\
1883 \\
1890 \\
1896\end{array}$ \\
\hline
\end{tabular}

\begin{tabular}{|c|c|c|c|}
\hline \multirow{2}{*}{$\begin{array}{l}\text { Serial } \\
\text { No. }\end{array}$} & \multirow{2}{*}{ Children } & \multicolumn{2}{|c|}{ Date of Birth } \\
\hline & & Father & Mother \\
\hline $\begin{array}{l}214 \\
216 \\
227 \\
229 \\
230 \\
245 \\
248 \\
249 \\
260 \\
272 \\
283 \\
284 \\
293 \\
297 \\
383 \\
477 \\
484 \\
485 \\
486 \\
488 \\
491 \\
493 \\
495 \\
497 \\
499 \\
501 \\
506 \\
511 \\
513 \\
514 \\
515 \\
517 \\
520 \\
521 \\
523 \\
526 \\
530 \\
533 \\
536\end{array}$ & 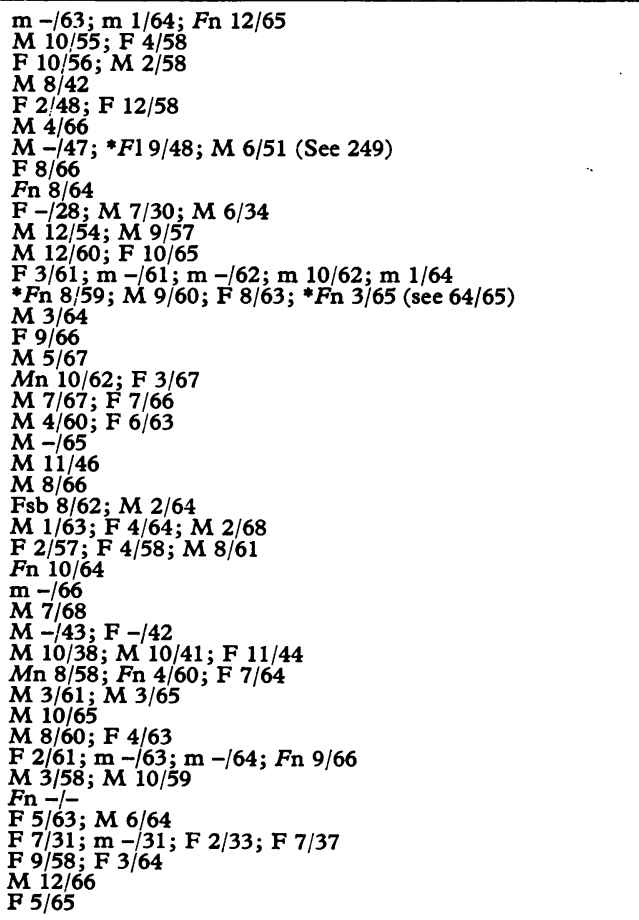 & $\begin{array}{r}1936 \\
* 1944 \\
1937\end{array}$ & $\begin{array}{l}* 1938 \\
* 1925 \\
* 11930 \\
* 1915 \\
* 1916 \\
* 1942 \\
* 1926 \\
* 1948 \\
* 1940 \\
* 1902 \\
* 1927 \\
* 1937 \\
* 1941 \\
* 1933 \\
* 1935 \\
* 1942 \\
* 1939 \\
* 1930 \\
* 1936 \\
* 1946 \\
* 1918 \\
* 1940 \\
* 1938 \\
* 1943 \\
* 1934 \\
* 1938 \\
* 1943 \\
* 1943 \\
* 1915 \\
* 1939 \\
* 1934 \\
* 1942 \\
* 1936 \\
* 1933 \\
* 1936 \\
* 1943 \\
* 1942 \\
* 1912 \\
* 1933 \\
* 1933 \\
* 1941 \\
\end{array}$ \\
\hline
\end{tabular}


Appendix-continued

\begin{tabular}{|c|c|c|c|}
\hline \multirow{2}{*}{$\begin{array}{l}\text { Serial } \\
\text { No. }\end{array}$} & \multirow{2}{*}{ Children } & \multicolumn{2}{|c|}{ Date of Birth } \\
\hline & & Father & Mother \\
\hline $\begin{array}{l}537 \\
538 \\
540 \\
541 \\
543 \\
544 \\
545 \\
547 \\
549 \\
555 \\
556 \\
557 \\
560 \\
561 \\
562 \\
563 \\
566 \\
567 \\
571 \\
572 \\
575 \\
577 \\
579 \\
580 \\
582 \\
585 \\
587 \\
589\end{array}$ & 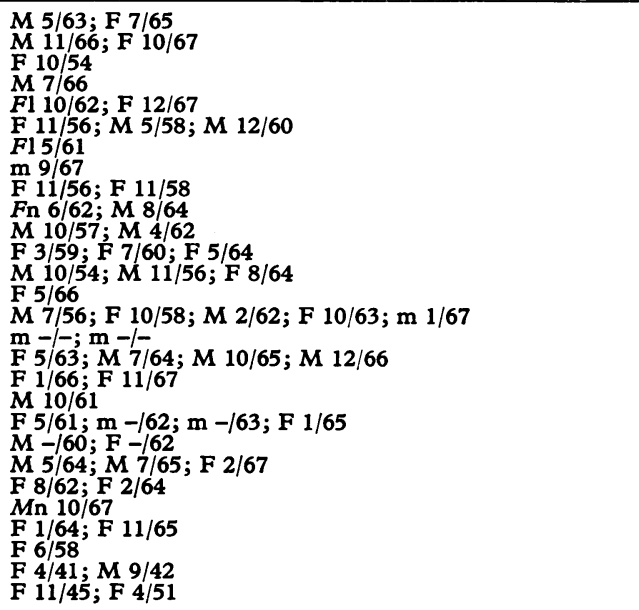 & $* 1927$ & $\begin{array}{l}* 1940 \\
* 1944 \\
* 1931 \\
* 1947 \\
* 1934 \\
* 1930 \\
* 1927 \\
* 1927 \\
* 1929 \\
* 1937 \\
* 1931 \\
* 1927 \\
* 1943 \\
* 1925 \\
* 1942 \\
* 1943 \\
* 1941 \\
* 1934 \\
* 1938 \\
* 1937 \\
* 1940 \\
* 1939 \\
* 1942 \\
* 1933 \\
* 1923 \\
* 1915 \\
* 1921\end{array}$ \\
\hline
\end{tabular}

